\title{
Iron in Multiple Sclerosis and Its Noninvasive Imaging with Quantitative Susceptibility Mapping
}

\author{
Carsten Stüber ${ }^{1,2, *}$, David Pitt ${ }^{2}$ and Yi Wang ${ }^{1,3}$ \\ Received: 29 May 2015; Accepted: 7 January 2016; Published: 14 January 2016 \\ Academic Editors: Christoph Kleinschnitz and Sven Meuth \\ 1 Department of Radiology, Weill Cornell Medical College, New York, NY 10044, USA; yw233@cornell.edu \\ 2 Department of Neurology, Yale School of Medicine, Yale University, New Haven, CT 06511, USA; \\ david.pitt@yale.edu \\ 3 Department of Biomedical Engineering, Cornell University, Ithaca, NY 14853, USA \\ * Correspondence: cas2050@med.cornell.edu; Tel.: +1-646-962-2637; Fax: +1-212-746-4189
}

\begin{abstract}
Iron is considered to play a key role in the development and progression of Multiple Sclerosis (MS). In particular, iron that accumulates in myeloid cells after the blood-brain barrier (BBB) seals may contribute to chronic inflammation, oxidative stress and eventually neurodegeneration. Magnetic resonance imaging (MRI) is a well-established tool for the non-invasive study of MS. In recent years, an advanced MRI method, quantitative susceptibility mapping (QSM), has made it possible to study brain iron through in vivo imaging. Moreover, immunohistochemical investigations have helped defining the lesional and cellular distribution of iron in MS brain tissue. Imaging studies in MS patients and of brain tissue combined with histological studies have provided important insights into the role of iron in inflammation and neurodegeneration in MS.
\end{abstract}

Keywords: MS lesion; quantitative susceptibility mapping (QSM); deep grey matter (DGM); MRI

\section{Introduction}

Iron as an electron facilitator is involved in healthy brain functions including myelin production, oxygen transport and neurotransmitter synthesis [1-3]. Excessive brain iron levels are invariably associated with neurodegenerative diseases, such as Alzheimer's disease, amyotrophic lateral sclerosis and Parkinson's disease [1,4]. Multiple sclerosis (MS) is an inflammatory disease of the central nervous system that also has neurodegenerative features [5,6]. Iron has been shown to accumulate in deep grey matter (DGM) nuclei of patients with MS and in white matter (WM) lesions [7-10]. Thus, there is an increased interest in quantifying iron in MS patients with noninvasive magnetic resonance imaging (MRI) that is sensitive to the magnetic field generated by tissue iron [8-43]. However, conventional MRI methods for detecting or measuring iron suffer from blooming artifacts due to the nonlocal nature of magnetic field. Quantitative susceptibility mapping (QSM) [44,45] provides a field-to-source deconvolution approach to iron quantification, overcoming the blooming artefact problem in conventional MRI $[41,46]$. Here, we review the physiological role of iron in the healthy brain, the progress made in brain iron mapping through MRI methods and the contribution of iron to MS pathophysiology.

\section{Iron Detection Methods}

We briefly review the tools that can be used to detect iron in tissue, including histological techniques and elemental analysis tools to quantitatively measure iron in tissue samples. We also review non-invasive MRI techniques for in vivo study of brain iron, which are important for translating tissue studies into clinical practice and for in vivo biological and pathophysiological investigations. 


\subsection{Ex-Vivo Iron Detection and Measurement}

We first discuss qualitative and quantitative ex vivo methods for studying tissue iron, which can be considered as the gold standard for studying iron chemistry and quantity.

\subsubsection{Qualitative Detection of Iron-Histology}

$\mathrm{Fe}^{3+}$ staining (Perls' Prussian blue) and $\mathrm{Fe}^{2+}$ staining (Turnbull's blue) have been used for qualitatively exploring the distribution of iron in brain tissue. Because most iron in the brain is present as ferric $\left(\mathrm{Fe}^{3+}\right)$ iron, Perls' staining is the most commonly used technique to visualize iron histologically. In addition, immunohistochemical labeling is used for iron-related proteins, including ferritin [10,47,48], transferrin [47,49,50] and ceruloplasmin [51]. However, presence of ferritin does not necessarily reflect presence of iron, as has been shown in myeloid cells where ferritin can be present in the absence of iron [9].

\subsubsection{Quantitative Detection of Iron-Spectrometric Techniques}

A few spectrometric techniques are available to quantify iron in biological tissue, which are either based on the characteristic atomic mass [52] or element-specific characteristic X-rays emitted from atomic inner shell transitions [53]. Spectrometric methods measure iron irrespective of its chemical state, i.e., $\mathrm{Fe}^{2+}$ or $\mathrm{Fe}^{3+}$, thus quantifying the total iron content. Here is a brief outline of commonly used iron quantification methods:

- Colorimetry: This iron-detecting approach requires a standard of the measured absorbance for known concentrations, thus making it problematic for comparing tissue samples of different measurements $[47,54,55]$.

- Atomic Absorption Spectrometry or Spectrophotometry (AAS): The technique equally requires standards with known analyte content to establish a relationship between measured absorbance and analyte concentration [56-58].

- Instrumental Neutron Activation Analysis (INAA): The intensity and wavelength of the signal is element-specific and can be used to characterize the examined sample [59-61].

- Inductively Coupled Plasma Mass Spectrometry (ICP-MS) [4,62,63]: ICP-MS has become the most prominent method to quantitatively correlate iron concentration and MR-signal, in particular iron and R2* [17,64-67], although a quantitative mapping of the elemental distribution is not possible. However, ICP-MS in combination with laser ablation (LA-ICP-MS) allows for microlocal element analysis $[68,69]$. LA-ICP-MS has been use to quantitatively map the iron distribution of brain tissue [41,70].

- X-ray Fluorescence Spectrometry (XRF) or Rapid Scan X-ray fluorescence spectrometry (RS-XRF) [71,72]: This technique allows for iron mapping and experiments have been conducted at two different locations; at the Stanford Synchrotron radiation laboratories (SSRL) [73] or more recently at the new Diamond light source in Oxfordshire, UK [74].

- Proton-Induced X-ray Emission (PIXE) [75-77]: A similar principle as XRF allowing to create iron maps of brain tissue [78-80].

RS-XRF, PIXE and LA-ICP-MS are the only techniques that can been applied to correlate MR signal and local iron concentration voxel by voxel $[41,71,81]$. These techniques can be utilized as the gold standard for mapping the local iron tissue concentration.

\subsection{In Vivo Iron Detection and Measurement}

Noninvasive MRIs are highly sensitive to tissue iron content and has become the method of choice for investigating brain iron, including iron in MS brains. We review first the qualitative MRI methods for detecting iron, semi quantitative methods for measuring iron, and then describe quantitative susceptibility mapping (QSM) for biophysics model based iron quantification. 


\subsubsection{Qualitative MRI Methods}

MRI offers rich tissue contrasts to sensitize tissue compositions and biophysical processes. Traditional $\mathrm{T} 2$ and $\mathrm{T} 2 *$ relaxation contrasts have been used to detect brain iron; $\mathrm{T} 1$ relaxation has been shown to be slightly affected by iron, but not as strongly as T2 or T2* [81-85]. Here, we summarize T2 and $\mathrm{T}^{*}$ based methods for detecting brain iron:

- T2-weighted imaging (T2w). Iron appears hypointense on T2-weighted images because paramagnetic iron produces a field in its surroundings, contributing to the incoherent thermal dephasing, i.e., enhancing the transverse relaxation rate 1/T2 = R2. Iron R2 enhancement increases with magnetic field strength [12]. Iron concentration has been shown to linearly correlate with R2 in DGM nuclei where iron distribution may be regarded as uniform [12,82,86-88]. However, the relationship remains difficult in both cortical grey matter (GM) and WM, due to the complex geometry of iron distribution [87].

- $\quad \mathbf{T}^{*}$ weighted imaging $\left(\mathrm{T} 2{ }^{*} \mathbf{w}\right)$. This magnitude gradient echo imaging (GRE) based $\mathrm{T} 2^{*}$ contrast is sensitive to the intravoxel variation of the iron induced magnetic field [89], in additional to the T2 contrast. $\mathrm{T} 2{ }^{*} \mathrm{w}$ is more sensitive to iron than $\mathrm{T} 2 \mathrm{w}$ and has become the method of choice for in vivo iron detection [90-92]. An enhanced version of $\mathrm{T} 2^{*} \mathrm{w}$ is susceptibility weighted imaging (SWI), which applies a phase attenuation to further increase the hypointensity contrast in $\mathrm{T} 2{ }^{*} \mathrm{w}[17,93]$. SWI contains more blooming artifacts than $\mathrm{T} 2^{*} \mathrm{~W}$. However, $\mathrm{T} 2^{*} \mathrm{~W}$ and SWI do not directly reflect the iron concentration due to their blooming artifacts and dependence on imaging parameters.

\subsubsection{Semi-Quantitative MRI Methods}

Quantifying iron from MRI data has long been a desired goal. A number of MRI metrics have been investigated, which are proportionate to iron content in limited situations. However, these methods are essentially based on the magnetic field, which contains blooming artifacts, i.e., depends on both local iron in a voxel and iron outside the voxel of interest.

- Magnetic Field Correlation Imaging (MFC) is directly related to iron-induced field variations and has been used to estimate iron concentration [22]. MFC bears similarity to R2' that is determined by the field variance in a voxel. MFC is estimated from a number of asymmetric spin echoes that are similar to gradient echoes [94,95].

- Phase Imaging. The gradient echo MRI data contains both magnitude and phase images. Traditionally, the phase images have been discarded and only the magnitude images are saved on the MRI scanner. The phase shift divided by the gyromagnetic ratio is the echo time times the iron induced magnetic field, which is proportional to the iron concentration convolved with the dipole kernel $[96,97]$.

- $\quad \mathbf{R} 2^{*}$ mapping. A number of correlation studies show that iron content is linearly related to the $1 / \mathrm{T} 2^{*}=\mathrm{R} 2 *$ in DGM nuclei where iron distribution is approximately constant $[87,98]$. However, $\mathrm{R} 2 *$, consisting of iron-enhanced R2 and iron-caused intravoxel dephasing (R2'), does not reflect local tissue iron concentration when its distribution is nonuniform. As a consequence, solid and shell MS lesions might be indistinguishable on R2* maps. Furthermore, R2* depends on imaging parameters [66,99], and suffers from blooming artifacts, nonlinearity, background field variations and other errors [99-104].

In summary, current traditional MRI quantification methods do not provide absolute quantification (some scaling factor remains to be determined), and suffer from being non-local, i.e., their values at a given voxel depend not only on the iron content in that voxel but also on iron concentration in the nearby voxels with a distance and direction dependent weighting [105].

\subsection{Quantitative Susceptibility Mapping (QSM)}

The GRE phase images or, more precisely, the magnetic field can be deconvolved to accurately determine the distribution of magnetic source-tissue susceptibility, which is quantitative susceptibility 
mapping (QSM). QSM eliminates blooming artifacts and quantifies the local tissue magnetic properties $[44,106,107]$. This field to source inversion has been made possible through the use of Bayesian inference and anatomic prior knowledge [44,45]. The inversion from field to susceptibility is known to be ill-posed [108]: there are zeroes in the kernel connecting the susceptibility distribution and the field, and a simple kernel division causes large errors that are present as streaking artifacts in the reconstructed susceptibility map $[109,110]$. Regularization is necessary to select a unique susceptibility solution for a given field [110-114]. In recent years, various regularizations have been tried for QSM reconstruction [44,106,107,115-125], reflecting different ways to impose known anatomic structural information in the desired QSM; they all demonstrated similar results [45]. While the QSM technology is still being actively developed, particularly to account for myelin contribution to magnetic susceptibility, current QSM is sufficiently robust and reliable for mapping highly paramagnetic brain iron, the dominant contributor to tissue susceptibility [110,126,127]. QSM divided by iron molar susceptibility generates the iron mass map for the iron-rich DGM nuclei $[98,115]$.

\section{Iron in Healthy Brains}

Iron is the most abundant trace metal in the healthy human brain, at levels 20-30 times higher than all other trace metals combined $[128,129]$. Iron levels increase nearly linearly with age from 0-20 years old for a developing brain, then they stay almost constant until 60 years old for a mature brain, and then further increase with age, ultimately causing neurodegeneration [54].

The majority of brain iron is present in the inactive form of ferric iron $\left(\mathrm{Fe}^{3+}\right)$ stored in the spherical shell of protein ferritin [130]. A small amount $(25)$ of brain iron is present in the active form of ferrous iron $\left(\mathrm{Fe}^{2+}\right)$. Iron transporter proteins including transferrin, DMT1 (divalent metal transporter) and ferroportin can transport $\mathrm{Fe}^{2+}$ ions. When ferrous iron is not needed, the $\mathrm{H}$-subunit of ferritin oxidizes ferrous iron into ferric iron and stores it in ferritin [49]. On the contrary, ferric iron can be readily converted by reductants and chelators into ferrous iron [131]. The brain iron level is delicately maintained by iron-regulating proteins for ferritin, iron transporters, and transporter receptors, forming a precise iron homeostasis that is critical for healthy brain function [132]. Disruption of brain iron homeostasis leads to neurological diseases, where iron overloading in various part of the brain leads to neurodegenerative diseases, including MS $[1,9,10,36]$.

Brain iron is stored in tissue cells where neurochemical processes require iron. The highest iron concentrations are found in the nuclei in the DGM in the midbrain, including globus pallidus (21 $\pm 3 \mathrm{mg}$ iron/100 $\mathrm{g}$ fresh weight ( $\mathrm{fw})$, mature brain), red nucleus (19 $\pm 7 \mathrm{mg}$ iron/100 $\mathrm{g} \mathrm{fw})$, substantia nigra (18 $\pm 7 \mathrm{mg}$ iron/100 $\mathrm{g} \mathrm{fw})$ and putamen ( $13 \pm 3 \mathrm{mg}$ iron/100 $\mathrm{g} \mathrm{fw})$ [54]. These midbrain nuclei constantly generate neurotransmitters including dopamine and glutamate to maintain signal traffic in brain circuits, and these neurotransmitter syntheses seem to require electron facilitation by iron. There is also substantial amount of iron in cortical grey regions including the motor $(5 \pm 1 \mathrm{mg}$ iron $/ 100 \mathrm{~g} \mathrm{fw}$, mature brain), occipital $(4.6 \pm 0.7 \mathrm{mg}$ iron $/ 100 \mathrm{~g} \mathrm{fw})$, sensory $(4.3 \pm 0.6 \mathrm{mg}$ iron $/ 100 \mathrm{~g} \mathrm{fw})$ parietal $(3.8 \pm 0.7 \mathrm{mg}$ iron $/ 100 \mathrm{~g} \mathrm{fw})$, temporal $(3.1 \pm 0.6 \mathrm{mg}$ iron $/ 100 \mathrm{~g} \mathrm{fw})$ and prefrontal cortex $(3 \pm 0.4 \mathrm{mg}$ iron/100 $\mathrm{g} \mathrm{fw})[54,109]$.

WM iron is more homogeneously distributed compared to the variations found in GM. The WM iron concentration is higher in the frontal lobe and lower in the occipital lobe compared to adjacent cortical GM indicating a gradient in iron concentration $[48,81,133]$. Cells containing iron cluster around blood vessels in WM give a patchy appearance on a microscopic scale $[47,134]$. Oligodendrocytes contain substantial amounts of iron [134], which is necessary for their large metabolic activity including the synthesis of myelin $[60,62]$. In the midbrain DGM, neurons and astrocytes also have a substantial amount of iron [51].

\section{Iron in Multiple Sclerosis}

The pathological hallmark of MS is inflammatory demyelination in both white and gray matter. Demyelination is mediated by myelin protein-specific $\mathrm{T}$ cells and myelin-phagocytosing macrophages. 
It is well documented that iron is retained by macrophages during inflammation [135]; however, macrophage iron uptake strongly depends on their state of activation. Activated macrophages can assume a continuum of polarization states, which may include one band of "classical" or proinflammatory M1 activation, and another band of anti-inflammatory M2 activation.

M1 macrophages secrete high levels of proinflammatory cytokines and reactive oxygen species and have increased microbiocidal capability while M2 macrophages dampen proinflammatory cytokine levels, have a high scavenging capacity and are essential for late phase tissue repair [136-138]. Moreover, M1 polarization is associated with high intracellular iron content, while M2 polarization is associated with enhanced iron release and low intracellular iron $[139,140]$. In addition, iron uptake itself has been shown to promote a proinflammatory state in macrophages through activation of NF- $\mathrm{kB}$, a master regulator of the innate and adaptive immune system [141,142]. More recently, the M1-M2 paradigm for macrophages has been criticized as too bipolar and other models are now being proposed that take the complex and possibly mixed macrophage phenotypes into account [143].

\subsection{Iron in White Matter MS Lesions}

WM lesions are characterized by an initial infiltration of activated T cells and macrophages, demyelination and blood-brain barrier (BBB) breakdown. Iron is absent from early active, gadolinium-enhancing lesions as suggested by imaging studies of MS patients and by MRI and histological analysis of MS brain tissue [10,41,42,144]. At this early stage, macrophages contain myelin fragments and are M2 polarized [145], which is associated with low iron content (Figure 1).

A retrospective QSM imaging study of MS patients showed that lesion susceptibility values increase sharply as lesions become non-enhancing and remain high for several years [42]. Histologically, these lesions show no or minimal active demyelination but contain iron-rich microglia, predominantly at the lesion rim [146] (Figure 1). The presence of iron in these microglia cells presumably propagates chronic, low-grade and proinflammatory activation not associated with demyelination that may ultimately contribute to neurodegeneration and disease progression. The sources of iron in microglia in MS lesions are likely oligodendrocytes and myelin, who, upon their destruction, release iron into the extracellular space [9].

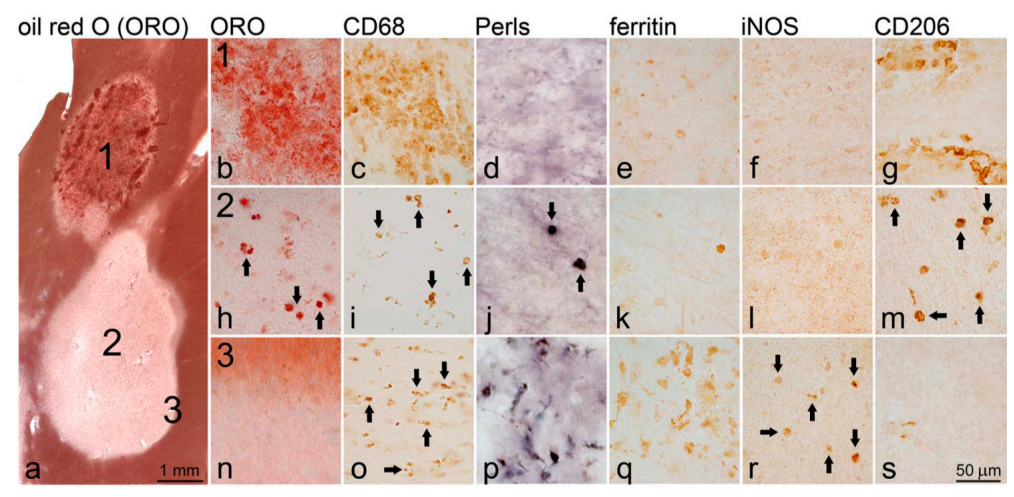

Figure 1. Iron deposition in white matter MS lesions. The overview image (a) shows an oil-red O-stained with an actively demyelinating lesion (1) and a demyelinated lesion (2); The actively demyelinating lesion [1] contains myelin-laden macrophages as indicated by oil-red $\mathrm{O}(\mathrm{ORO})$ positive material within $\mathrm{CD}^{+} 8^{+}$macrophages $(\mathbf{b}, \mathbf{c})$; These macrophages do not contain iron, indicated by Perls' staining (d); or the iron-storage protein ferritin (e); and display markers indicative of M2 polarization (iNOS ${ }^{-}(\mathbf{f})$ and $\mathrm{CD}^{206}{ }^{+}(\mathrm{g})$ ); The demyelinated lesion center (2) shows CD68 ${ }^{+}$macrophages (black arrows) containing condensed myelin (h,i); occasionally containing iron (j) and correspondingly ferritin (k); and expressing CD206 (m); but not iNOS (1). In contrast, the demyelinated lesion rim (3) shows microglia (black arrows) containing no ORO positive material (n,o); but large amounts of iron (p) and iron-storing ferritin (q); These cells are iNOS positive (r) and CD206 negative (s) suggestive of M1-like polarization. (Source: [10]). The black arrows are indicating macrophages. 
Finally, chronic silent lesions, i.e., longstanding lesions that no longer contain inflammatory cells have low susceptibility values, thus indicating low iron content [42].

\subsection{Iron in Cortical MS Lesions}

Iron content has also been examined in cortical lesions. We found that activated microglia at the border of chronic active cortical lesions contained high amounts of iron [147], consistent with our findings in chronic active WM lesions. A study that examined silent cortical lesions, i.e., lesions that did not contain inflammatory cells, found that iron density was reduced compared to normal appearing GM [148]. This iron loss is presumably caused by depletion of iron-containing oligodendrocytes and myelin sheaths from cortical lesions and possibly from neurons.

\subsection{Iron in Normal Appearing White Matter (NAWM)}

A recent histopathological report suggests that iron is lost from Normal Appearing White Matter (NAWM) and that this loss becomes more pronounced with increasing disease duration [9]. This observation is corroborated by an MRI study of MS patients that reports reduced $\mathrm{R}_{2}{ }^{\prime}$ signal in NAWM of MS patients as compared to controls [25]. Iron depletion from oligodendrocytes may compromise myelin and ultimately axonal integrity in myelinated white matter, a pathology that is thought to play a prominent role in chronic progressive MS [9,37].

\subsection{Iron in Deep Gray Matter of MS Patients}

Increased iron deposition has been observed in the deep nuclei of MS patients, predominantly in the putamen [33,34] (Figure 2). Moreover, it has been demonstrated that iron correlates better than any conventional measure with physical disability [149], brain atrophy [150-152], cognitive dysfunction [152] and risk of developing sustained progression of disability [88]. Iron accumulation in the basal ganglia during aging is accelerated in neurodegenerative diseases $[2,153,154]$. The cell type(s) in which iron accumulates in DGM in MS are currently unknown. Similarly, it has not been examined whether iron deposits are directly associated with cellular pathology. It is tempting to speculate that iron overload induces neuronal degeneration through enhanced free radical production and oxidative stress, as it has been shown in Parkinson's disease [155].

healthy control

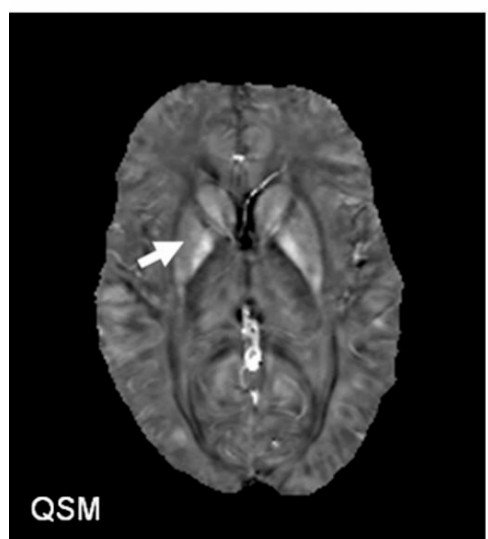

\section{MS patient}

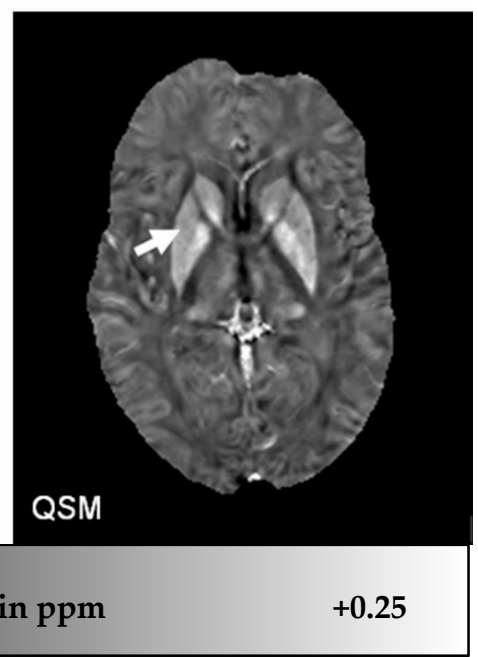

Figure 2. QSM map of a HC subject (29 y) and an MS patient (29 y). Note increased susceptibility in the basal ganglia of the MS patient indicating increased iron content. Susceptibility differences are most evident in the putamen (white arrow, 0.049 vs. 0.092 ppm). (Source: [46]). 
In summary, brain iron homeostasis is profoundly perturbed in MS, involving different compartments and resulting in various pathologies. First, iron accumulates after initial acute demyelination in activated microglia at the rim of white matter lesions, where it might contribute to long-lasting (several years) neurotoxic inflammation. Moreover, with increasing disease duration, iron is slowly depleted from normal appearing white matter, which potentially compromises oligodendrocyte functions including myelin maintenance and contributes to axonal damage outside of white matter lesions [60]. Iron is also depleted in inactive cortical lesions, which may affect neuronal function. Finally, iron accumulates at an increased rate in the deep nuclei of MS patients. Although the pathogenic significance of this has not been elucidated, iron deposition has been shown to correlate well with various measures of disability in MS and to be associated with neurotoxicity in other neurodegenerative diseases.

\section{Investigating Iron in MS}

Ex-vivo and in vivo qualitative and quantitative detection and measurement of brain iron levels is very useful for understanding the role of iron in MS pathogenesis, and for translating in vivo MRI patient studies.

\subsection{Ex-Vivo Methods to Detect Iron in MS}

A number of studies have used histology to characterize iron content in post-mortem brain tissue of MS patients, either employing $\mathrm{Fe}^{3+}$ stain $[31,41,147]$, in combination with immunohistochemical detection of ferritin $[10,144]$, or $\mathrm{Fe}^{2+}$ stain $[9,33,51]$ and in combination with ferritin $[20,28]$. Only one study has used a quantitative technique, LA-ICP-MS, to measure the iron concentration in MS lesions (Section 5.3.4; Figure 5) [41].

\subsubsection{Immunohistochemical (IHC) Analysis of Iron in MS Lesions [10]}

We explored the role of lesional iron in multiple sclerosis using multiple approaches: immunohistochemical examination of autoptic MS tissue (Figure 1), iron-uptake in human cultured macrophages and MRI of relapsing and secondary progressive MS patients. Using Perls' stain and immunohistochemistry, iron was detected in MS tissue sections predominantly in non-phagocytosing microglia at the edge of established lesions. Moreover, iron-containing microglia, but not myelin-laden macrophages, expressed markers of proinflammatory (M1) polarization. Similarly, in human macrophage cultures, iron was preferentially taken up by non-phagocytosing, M1-polarized macrophages and further induced M1 (super)polarization. Iron uptake was minimal in myelin-laden macrophages and active myelin phagocytosis by iron-laden macrophages led to the depletion of intracellular iron.

Iron deposits were more prevalent in WM lesions of patients with active relapsing-remitting MS than in patients with stable, longstanding disease. Together, these data suggest that iron accumulation in WM lesions are indicative of chronic, non-demyelinating inflammatory activity that occurs behind a closed blood-brain barrier and can be detected by QSM.

\subsection{In-Vivo Methods to Detect Iron in MS}

Noninvasive MRI has been the main window for studying MS. In particular, non-conventional MRI techniques have been increasingly used to better probe the MS pathological substrate, including Gradient echo (GRE) imaging, which is highly sensitive to iron and myelin distribution.

\subsubsection{Qualitative Iron Detection Using Conventional MRI Contrasts}

The magnetic susceptibility weighting in $\mathrm{T} 2 *$ contrasts becomes more prominent in Ultra-High Field MRI, allowing the study of DGM iron deposits with increased sensitivity for basal ganglia regions $[8,144,156,157]$ and WM lesions [158], and enabling investigation of small cortical lesions [159]. 
The noninvasive nature of MRI allows longitudinal studies to investigate the change of iron concentration over the progression of MS. Several longitudinal studies were performed in DGM structures and consistently showed a correlation between an increases in iron concentration with disease duration [38-40]. It has been found that iron accumulation is more pronounced in the early phase of the disease compared to the later stage [40]. The largest iron increase was observed in the substantia nigra and the globus pallidus in relapsing-remitting multiple sclerosis (RRMS) patients [38].

- T2-weighted imaging (T2w). T2 relaxometry has been applied to detect iron accumulation in DGM of MS patients showing a shortening of the T2 relaxation time for MS patients [19]. However, it is currently not possible to attribute changes in relaxation times to specific pathologic changes, which is crucial for lesion characterization [160]. Furthermore, in contrast to WM lesions and leukocortical lesions, intracortical lesions remain largely undetected in T2 [161]. WM lesions appear hyperintense on T2 due to demyelination (shown in Figures 3 and 6).



New (0y) enhancing lesions' susceptibilities increase



Figure 3. MS lesions on T1w (1st and 2nd row)/T2w (3rd and 4th row) and QSM at MRI1 (left, in blue) and a follow-up study at MRI2 (right, in black). The white boxes indicate the position of lesions identified on T1w, which are invisible on QSM. White arrows point at lesions in general; black arrows point at transient lesions, which disappear (appear T1 isointense) in the follow-up study (MRI2). Lower graphs: 32 cases are shown to exemplify lesions at various ages. The susceptibility of acute lesions $(0$ y) relative to NAWM jumped from MRI1 to MRI2 (red squares at bottom graph, interval between MR examinations $=0.43 \pm 0.16$ years). (Source: [42]). 
- $\quad \mathbf{T 2}{ }^{*}$ weighted imaging $\left(\mathbf{T} 2^{*} \mathbf{w}\right)$. Lesion magnetic susceptibility increases, as microglia degrade and remove diamagnetic myelin fragments $[10,162,163]$, and as $\mathrm{m} / \mathrm{M}$ take in highly paramagnetic iron $[9,10,13,20,31]$. Thus, in recent years, GRE sequences have been actively used to gain new insights into MS lesion inflammation activity $[8,15,17-19,21-25,28,29,38,42,164-166]$. Hypointense rings on $\mathrm{T} 2{ }^{*} \mathrm{w}$ images correlated with histologically demonstrated iron-laden microglia present at the edge of chronic active lesions [147], but both solid and shell lesions will generate rings on $\mathrm{T} 2^{*} \mathrm{w}$ images $[8,167]$ (shown in Figure 4).

- Susceptibility Weighted Imaging (SWI) SWI has been utilized to see differences of iron content in healthy subjects $v s$. MS patients [23] and to detect lesions in GM and WM [17,24,30,168,169].

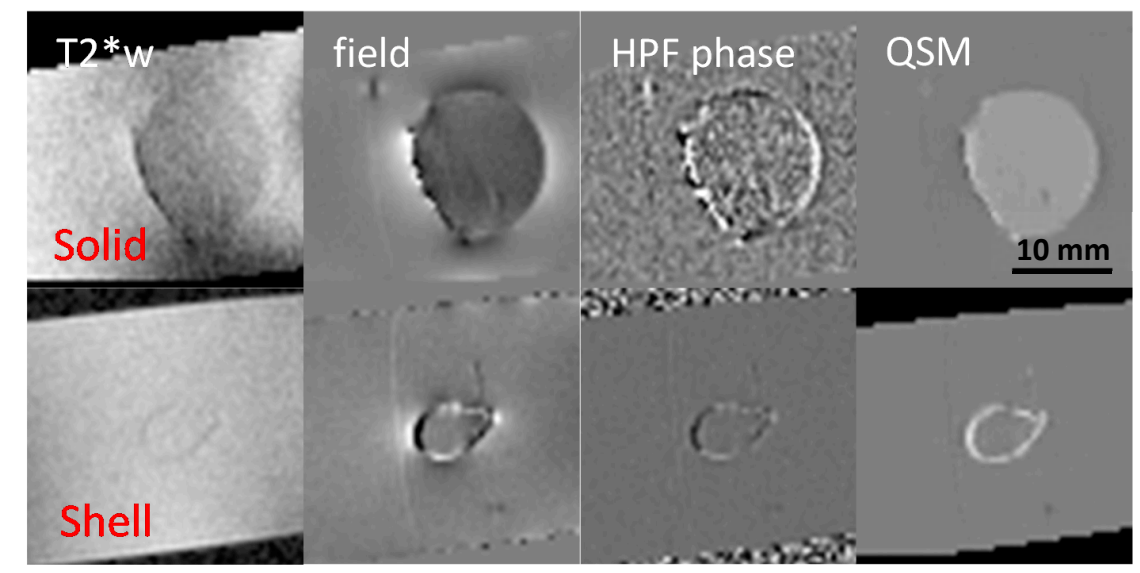

Figure 4. Solid and shell susceptibility (ultrasmall superparamagnetic iron oxide particles (USPIO)) object appearance in MRI techniques. Solid and shell lesions can be identified on QSM images; however, they both appear shell-like on phase images. (Source: [170]).

\subsubsection{Semi-Quantitative Iron Detection Using Conventional MRI Contrasts}

Iron quantification is highly desirable for monitoring disease progression and therapeutic outcome as well as for enabling longitudinal or cross-center studies. Here, we summarize three semi-quantitative methods that have been used for measuring iron in MS:

- Phase Imaging. MS lesions may appear isointense or hypointense on phase images $[24,166]$. It should be noted that both solid and shell (ring in 2D sectional image) lesions in MS brains have shell appearance, according to physics law and experimental data [170] (shown in Figure 4). The difficulty in interpreting GRE phase data of MS [162,164-166] is because phase is not a local tissue property, but a weighted summation of the magnetic properties of the surrounding tissue. Thus, phase cannot be used to quantify local iron density, which was validated experimentally [66].

- $\quad 2^{*}$ Mapping. An increased R2* has been observed in the DGM structures of MS patients, indicating increased iron content $[21,35,171,172]$. T2* or R2* mapping has been used to investigate intracortical and leukocortical lesions $[147,173,174]$.

- Magnetic Field Correlation Imaging (MFC) MFC has been utilized to measure increased iron content in MS patients $[15,34]$. However, MFC has the most R2* limitations discussed above.

\subsection{Quantitative Susceptibility Mapping (QSM)}

Important for MS applications, QSM is more sensitive than $\mathrm{R}^{*}$ in detecting pathological changes in the basal ganglia [46], allowing iron quantification in completely demyelinated areas [170]. QSM quantitation enables time course investigation that is organizing MS lesion heterogeneity into lesion dynamics [42]. Correcting for myelin contribution using myelin water fraction (MWF) [175-177] 
and diffusion tensor imaging (DTI) [41,178], QSM can quantitatively map iron, possibly representing inflammatory microglia [41]. Here, we summarize QSM and pathology findings in MS.

\subsubsection{Shell vs. Solid Lesions [170]}

Differentiating solid from shell lesions is important for understanding MS lesion pathology $[9,10]$, but this is challenging on phase images. Solid and shell susceptibility sources were correctly reconstructed on QSM, while the high pass filtered (HPF) phase and field images depicted both geometries with the same shell-like pattern (Figure 4). Twenty MS cases were reviewed by a neuroradiologist; of the 21 lesions that appeared as rings on HPF phase, $14(66 \%)$ appeared as solids and seven $(33 \%)$ appeared as rings on QSM.

\subsubsection{MS Lesion Susceptibility Time Course Study [42]}

Thirty-two clinically confirmed MS patients underwent two MR exams (denoted by MRI1 and MRI2) with $0.43 \pm 0.16$ year (y) interval on a 3T scanner. MRI included T2w, T1w, T1w $+\mathrm{c}$ and QSM $(20,21)$. Ages of 162 lesions were measured by examining their first appearance on prior MRIs (over past 0.3-10.6 y) in PACS. The susceptibilities relative to NAWM and temporal rates of change in lesion susceptibility relative to CSF were $0.53 \pm 3.34 \mathrm{ppb}$ (parts per billion) and $9.29 \pm 1.84 \mathrm{ppb} /$ month $(\mathrm{m})$ for new enhancing lesions (age = $0 \mathrm{y}$ ), $38.0 \pm 13.6 \mathrm{ppb}$ (higher than NAWM, $p<0.01$ ) and $1.3 \pm 2.3 \mathrm{ppb} / \mathrm{m}$ (not different from zero, $p=0.38$ ) for nonenhancing lesions at age $=0-4 \mathrm{y}$, and $4.67 \pm 3.18 \mathrm{ppb}$ and $-0.11 \pm 0.55 \mathrm{ppb} / \mathrm{m}$ for old nonenhancing lesions (age $>7 \mathrm{y}$ ). Examples are presented in Figure 3, showing that lesion susceptibility initially jumped from that of NAWM to high values for $0 \mathrm{y}$ enhancing lesions (top two rows), became stable at high values for the $1.2 \mathrm{y}$ nonenhancing lesions ( $3 \mathrm{rd}$ row), and decayed back to that of NAWM for the $10+y$ nonenhancing lesions (4th row). Individual lesion values at MRI1 and MRI2 time points (Figure 3, bottom row), clearly demonstrate the initial jump (red points).

\subsubsection{QSM Is More Sensitive Than R2* in Detecting MS Basal Ganglia Change [46]}

Sixty-eight patients (26 clinically isolated syndrome (CIS), 42 relapsing-remitting MS) and 23 healthy control (HC) subjects underwent 3T MRI. QSM and R2* maps were reconstructed from the same 3D multiecho spoiled GRE sequence. QSM successfully detected the difference in caudate nucleus and putamen between HC and CIS subjects, and difference in globus pallidus between HC and MS subjects while R2* failed to do so. Susceptibilities were higher with increasing neurologic deficits $(r=0.34, p<0.01)$ (Figure 2).

5.3.4. QSM, Laser Ablation Inductively Coupled Plasma Mass Spectrometry (LA-ICP-MS) and Immunohistochemical (IHC) Labeling for Myelin Basic Protein (MBP) and Myeloid Cells (CD68) [41]:

Both iron deposition and demyelination in MS lesions can cause a susceptibility increase as measured by QSM [179], but their relative contributions are unclear. LA-ICP-MS [70] provides highly sensitive elemental analysis. IHC labeling for MBP and CD68 detects the presence or absence of myelin and myeloid cells, respectively. We performed MRI (QSM, phase, T2* $\left.\mathrm{w}, \mathrm{R} 2^{*}\right)$, LA-ICP-MS, MBP and CD 68 labeled ICH on a WM MS lesion (Figure 5). Quantitative [Fe] maps, acquired with LA-ICP-MS were converted to susceptibility $1.4 \mathrm{ppb}^{*}([\mathrm{Fe}] / \mu \mathrm{g} / \mathrm{mL})$ using the molar susceptibility of 3.78 Bohr magnetons per iron at room temperature [128] and a tissue density of $1.04 \mathrm{~g} / \mathrm{cm}^{3}$ [180]. The myelin phospholipid fraction (PF) was estimated from the residual susceptibility QSM $-1.4^{*}[\mathrm{Fe}]$ using the mean molar susceptibility $-449 \mathrm{ppb}(\mathrm{L} / \mathrm{mol})$. The lesion had a negligible $\mathrm{PF}(<0.07$ at lesion center; $\sim 0.2-4$ for NAWM) and the interior showed susceptibility $29 \pm 7.5 \mathrm{ppb}$ on QSM, which is approximately fully explained by $27 \pm 7.5 \mathrm{ppb}$ contribution from [Fe]. The IHC stains (Figure 5: MBP, CD68) show absence of myelin and low level of $\mathrm{m} / \mathrm{M}$ in the lesion center, indicating a possibly inactive lesion aged 1-3 y (Figure 5). 


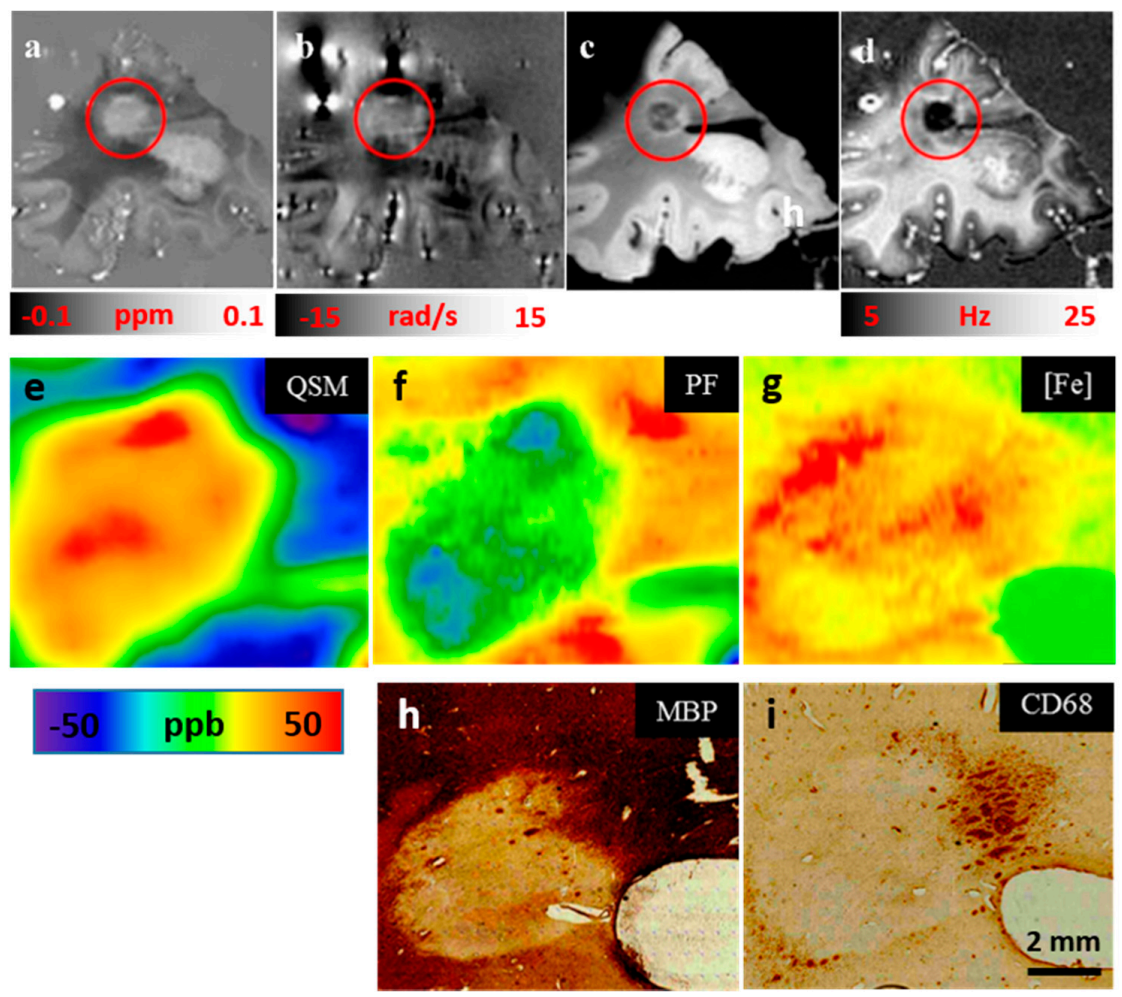

Figure 5. WM lesion (in red circle) appearing hyperintense on QSM (a); indicating high susceptibility and corresponding significant iron deposition, isointense on phase (b); hypointense on $\mathrm{T} 2{ }^{*} \mathrm{~W}(\mathbf{c})$ and R2* (d). Magnification of lesion within red circle (e-i): The LA-ICP-MS measures all forms of iron $\left(\mathrm{Fe}^{2+}, \mathrm{Fe}^{3+}\right)$, shown in (g); QSM mainly reflects ferritin-stored $\mathrm{Fe}^{3+}(\mathbf{e})$; Thus, iron maps were converted into susceptibility maps assuming a molar susceptibility of iron similar to that of ferritin at room temperature. Using the Langevin equation, iron contributes $\chi_{[\mathrm{Fe}]}=1.4 \mathrm{ppb}^{*}[\mathrm{Fe}]$, where $[\mathrm{Fe}]$ represents the local iron concentration. The phospholipid map (PF) (f), representing myelin, was calculated as $\chi_{\text {Myelin }}=\mathrm{QSM}-1.4 \mathrm{ppb}^{*}[\mathrm{Fe}]$ assuming that myelin is the major susceptibility component in WM [163]. PF (f) and MBP (h) indicate demyelination in the lesion center. CD68 stain (i) and iron map (g) indicate iron-rich microglia at the lesion rim. (Source: [41]).

\subsubsection{Iron Presence in a White Matter Lesion Can Often Be Unequivocally Identified on QSM}

Iron in white matter lesions can be identified at the hyperintense rim on QSM, in the QSM lesion volume lying outside the lesion volume on T2-weighted imaging, or with the positive QSM value relative to the CSF $[41,147,181,182]$ (Figure 6). The myelin contribution to susceptibility may be compensated using quantitative myelin water fraction imaging and diffusion tensor imaging, providing absolute iron quantification in general.
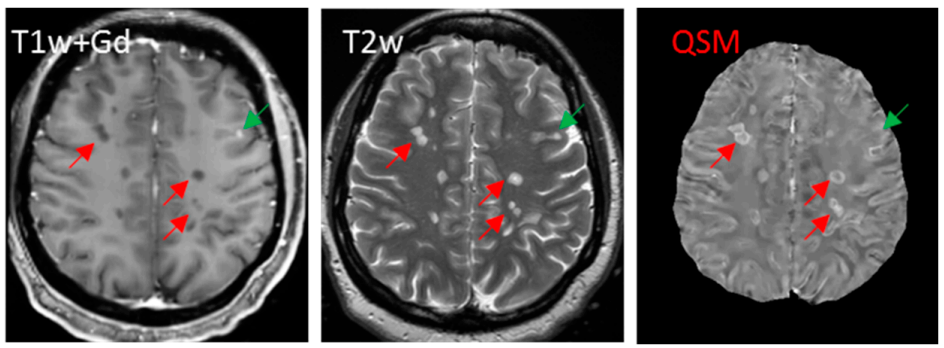

Figure 6. Non-enhancing lesions appear larger with hyperintense rim on QSM (red arrows) than on $\mathrm{T} 2 \mathrm{w}$, while enhancing lesions appear isointense on QSM (green arrow). 
In summary, iron-sensitive imaging of multiple sclerosis offers the possibility to monitor several aspects of MS pathology, in particular chronic microglial activation and shifts in iron concentrations in NAWM that cannot be measured by conventional MRI methods.

\section{Adding QSM in Clinical MS MRI Protocol to Improve Inflammation Monitoring}

Noninvasive MRI is critical for the diagnosis and surveillance of MS patients and is nowadays the main window for studying this neurodegenerative disease. Current inflammation assessment in clinical practice is based on gadolinium $(\mathrm{Gd})$ enhancement on contrast enhanced T1-weighted $(\mathrm{T} 1 \mathrm{w}+\mathrm{Gd}) \mathrm{MRI}$ [14]. However, Gd-enhancement is only an indirect measure of inflammation that is preceded and outlasted by the infiltration of immune cells [16] and is not reflective of the activation of resident innate immune cells of the central nervous system (CNS) [183]. T1w+Gd only offer a small time-frame of about three weeks for lesion detection, when the BBB is open for infiltration with immune cells [184]. Thus, T1w+Gd cannot capture the multiplicity of MS disease processes, resulting in poor pathological specificity [26] (Figure 7).

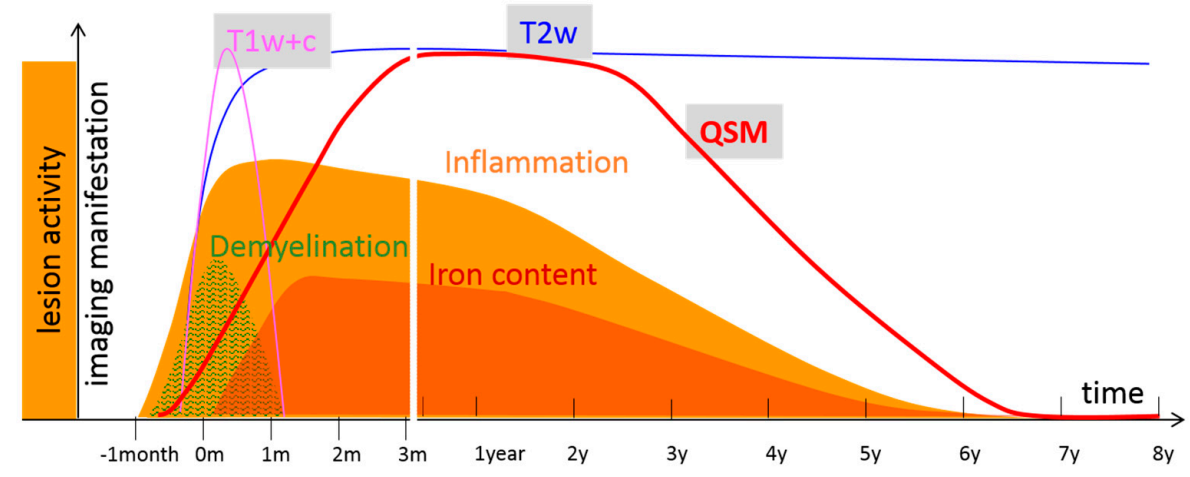

Figure 7. Lesion development over time showing various MS lesion activities (inflammation, iron deposition and emission (iron content)) and their manifestations on MRI (T1w+c, T2w, and QSM). Early inflammatory activity causes BBB damage, which is captured as Gd-enhancement on T1w+c; Immediate demyelination and iron deposition involving activated microglia cause rapid increase in magnetic susceptibility, which can be measured on QSM during MS lesion formation and development (approximately within the first 3 years (y)); Eventual old lesions (approx. >3 y) start to lose iron, which cancels the susceptibility increase of residual demyelination as measured by QSM. This time course indicates that QSM might be more sensitive than $\mathrm{T} 1 \mathrm{w}+\mathrm{c}$ in detecting inflammatory activity in lesions. QSM can detect both early and late inflammatory activity (remyelination is not frequently observed and not included here for simplicity).

QSM can be used to alleviate this situation. Myeloid cells during the Gd-enhancing period phagocytose myelin fragments, a process that is reflected in the initial lack of change in the susceptibility of active lesions on QSM. After the BBB is reconstituted, myeloid cells metabolize diamagnetic myelin fragments, and at the same time or afterwards, microglial cells at the lesion periphery accumulate paramagnetic iron [10]. Both myelin debris removal and iron accumulation likely contribute to the increase in lesion susceptibility observed on QSM. MS lesions are hyperintense, typically with bright lesion rims on QSM for about four years [42], that can be interpreted as iron [41] (Figure 6). Therefore, including QSM in MRI protocols for MS patient imaging may provide more information about the inflammatory status of lesions than Gd-enhancement alone (Figure 7).

Using QSM and T2w together can allow for accurate identification of lesions in MS patients without Gd injection (Figure 6), utilizing the fact that the magnetic susceptibility of an MS lesion increases rapidly as it changes from Gd-enhancing to non-enhancing [42]. We performed a preliminary study with the following findings [185]: a total of 126 new lesions were evaluated in 52 patients. Eighty-three lesions were identified as Gd-enhancing with their susceptibility 
values (2.46 \pm 6.40 parts-per-billion (ppb)) significantly lower than those of non-enhancing lesions $(19.92 \pm 7.80 \mathrm{ppb}, p<0.005)$. Receiver operating characteristic (ROC) analysis for discriminating enhancing and non-enhancing lesions using susceptibility values showed an area-under-the-curve of 0.956 . A cutoff-value of $11.2 \mathrm{ppb}$ for QSM-measured susceptibility provided a sensitivity of $89.2 \%$ and specificity of $90.7 \%$. Therefore, QSM can be used in routine MRI monitoring of new MS lesion activity to accurately identify the BBB leakage status of T2w lesions without gadolinium injection, which would be useful particularly for MS patients with contraindications for Gd injection.

\section{Conclusions}

Iron homeostasis in the MS brain is profoundly perturbed, with iron-overload in lesional myeloid cells and in deep nuclei on one hand, and diminished iron concentrations in NAWM and chronic cortical lesions on the other. These shifts are likely to contribute to low-grade chronic inflammation, oxidative stress and neurodegeneration. QSM can be used to detect iron changes and may thus improve our ability to monitor therapeutic efficacy and progression in MS.

In clinical practice, iron-sensitive imaging could therefore be used to aid treatment decisions in patients that appear clinically and radiographically stable but may have iron-positive, activated microglia within lesions. Moreover, accelerated resolution of iron accumulation could become an additional measure for treatment efficacy to reduce low-grade inflammation in established lesions.

Acknowledgments: This work was supported by National Multiple Sclerosis Society grant RG 4866-A-2. This work is supported in part by NIH R01NS090464 and R01EB013443. Funds for covering costs to publish in open access were not provided.

Author Contributions: All chapters were written by Carsten Stüber, Yi Wang and David Pitt.

Conflicts of Interest: Yi Wang is named one of the inventors for QSM technology.

\section{References}

1. Zecca, L.; Youdim, M.B.H.; Riederer, P.; Connor, J.R.; Crichton, R.R. Iron, brain ageing and neurodegenerative disorders. Nat. Rev. Neurosci. 2004, 5, 863-873. [CrossRef] [PubMed]

2. Stankiewicz, J.; Panter, S.S.; Neema, M.; Arora, A.; Batt, C.E.; Bakshi, R. Iron in chronic brain disorders: Imaging and neurotherapeutic implications. Neurotherapeutics 2007, 4, 371-386. [CrossRef] [PubMed]

3. Lieu, P.T.; Heiskala, M.; Peterson, P.A.; Yang, Y. The roles of iron in health and disease. Mol. Asp. Med. 2001, 22, 1-87. [CrossRef]

4. Dexter, D.T.; Carayon, A.; Javoy-Agid, F.; Agid, Y.; Wells, F.R.; Daniel, S.E.; Lees, A.J.; Jenner, P.; Marsden, C.D. Alterations in the levels of iron, ferritin and other trace metals in Parkinson's disease and other neurodegenerative diseases affecting the basal ganglia. Brain 1991, 114, 1953-1975. [CrossRef] [PubMed]

5. Trapp, B.D.; Nave, K.-A. Multiple sclerosis: An immune or neurodegenerative disorder? Annu. Rev. Neurosci. 2008, 31, 247-269. [CrossRef] [PubMed]

6. Nylander, A.; Hafler, D.A. Multiple sclerosis. J. Clin. Investig. 2012, 122, 1180-1188. [CrossRef] [PubMed]

7. Bakshi, R.; Benedict, R.H.B.; Bermel, R.A.; Caruthers, S.D.; Puli, S.R.; Tjoa, C.W.; Fabiano, A.J.; Jacobs, L. T2 hypointensity in the deep gray matter of patients with multiple sclerosis: A quantitative magnetic resonance imaging study. Arch. Neurol. 2002, 59, 62-68. [CrossRef] [PubMed]

8. Hammond, K.E.; Metcalf, M.; Carvajal, L.; Okuda, D.T.; Srinivasan, R.; Vigneron, D.; Nelson, S.J.; Pelletier, D. Quantitative in vivo magnetic resonance imaging of multiple sclerosis at 7 Tesla with sensitivity to iron. Ann. Neurol. 2008, 64, 707-713. [CrossRef] [PubMed]

9. Hametner, S.; Wimmer, I.; Haider, L.; Pfeifenbring, S.; Brück, W.; Lassmann, H. Iron and neurodegeneration in the multiple sclerosis brain. Ann. Neurol. 2013, 74, 848-861. [CrossRef] [PubMed]

10. Mehta, V.; Pei, W.; Yang, G.; Li, S.; Swamy, E.; Boster, A.; Schmalbrock, P.; Pitt, D. Iron is a sensitive biomarker for inflammation in multiple sclerosis lesions. PLoS ONE 2013, 8, 1-10.

11. Drayer, B.; Burger, P.; Darwin, R.; Riederer, S.; Herfkens, R.; Johnson, G.A. MRI of brain iron. AJR Am. J. Roentgenol. 1986, 147, 103-110. [CrossRef] [PubMed] 
12. Drayer, B.; Burger, P.; Hurwitz, B.; Dawson, D.; Cain, J. Reduced signal intensity on MR images of thalamus and putamen in multiple sclerosis: Increased iron content? AJR Am. J. Roentgenol. 1987, 149, 357-363. [CrossRef] [PubMed]

13. Adams, C.W. Perivascular iron deposition and other vascular damage in multiple sclerosis. J. Neurol. Neurosurg. Psychiatry 1988, 51, 260-265. [CrossRef] [PubMed]

14. Dousset, V.; Brochet, B.; Deloire, M.S.; Lagoarde, L.; Barroso, B.; Caille, J.M.; Petry, K.G. MR imaging of relapsing multiple sclerosis patients using ultra-small-particle iron oxide and compared with gadolinium. AJNR Am. J. Neuroradiol. 2006, 27, 1000-1005. [PubMed]

15. Ge, Y.; Jensen, J.H.; Lu, H.; Helpern, J.A.; Miles, L.; Inglese, M.; Babb, J.S.; Herbert, J.; Grossman, R.I. Quantitative assessment of iron accumulation in the deep gray matter of multiple sclerosis by magnetic field correlation imaging. AJNR Am. J. Neuroradiol. 2007, 28, 1639-1644. [CrossRef] [PubMed]

16. Vellinga, M.M.; Oude Engberink, R.D.; Seewann, A.; Pouwels, P.J.W.; Wattjes, M.P.; van Der Pol, S.M.A.; Pering, C.; Polman, C.H.; de Vries, H.E.; Geurts, J.J.G.; et al. Pluriformity of inflammation in multiple sclerosis shown by ultra-small iron oxide particle enhancement. Brain 2008, 131, 800-807. [CrossRef] [PubMed]

17. Haacke, E.M.; Makki, M.; Ge, Y.; Maheshwari, M.; Sehgal, V.; Hu, J.; Selvan, M.; Wu, Z.; Latif, Z.; Xuan, Y.; et al . Characterizing iron deposition in multiple sclerosis lesions using susceptibility weighted imaging. J. Magn. Reson. Imaging 2009, 29, 537-544. [CrossRef] [PubMed]

18. Khalil, M.; Enzinger, C.; Langkammer, C.; Tscherner, M.; Wallner-Blazek, M.; Jehna, M.; Ropele, S.; Fuchs, S.; Fazekas, F. Quantitative assessment of brain iron by $\mathrm{R}(2)^{*}$ relaxometry in patients with clinically isolated syndrome and relapsing-remitting multiple sclerosis. Mult. Scler. 2009, 15, 1048-1054. [CrossRef] [PubMed]

19. Burgetova, A.; Seidl, Z.; Krasensky, J.; Horakova, D.; Vaneckova, M. Multiple sclerosis and the accumulation of iron in the basal ganglia: Quantitative assessment of brain iron using MRI T(2) relaxometry. Eur. Neurol. 2010, 63, 136-143. [CrossRef] [PubMed]

20. Bagnato, F.; Hametner, S.; Yao, B.; van Gelderen, P.; Merkle, H.; Cantor, F.K.; Lassmann, H.; Duyn, J.H. Tracking iron in multiple sclerosis: A combined imaging and histopathological study at 7 Tesla. Brain 2011, 134, 3599-3612. [CrossRef] [PubMed]

21. Khalil, M.; Langkammer, C.; Ropele, S.; Petrovic, K.; Wallner-Blazek, M.; Loitfelder, M.; Jehna, M.; Bachmaier, G.; Schmidt, R.; Enzinger, C.; et al. Determinants of brain iron in multiple sclerosis: A quantitative 3T MRI study. Neurology 2011, 77, 1691-1697. [CrossRef] [PubMed]

22. Ropele, S.; de Graaf, W.; Khalil, M.; Wattjes, M.P.; Langkammer, C.; Rocca, M.A.; Rovira, A.; Palace, J.; Barkhof, F.; Filippi, M.; et al. MRI assessment of iron deposition in multiple sclerosis. J. Magn. Reson. Imaging 2011, 34, 13-21. [CrossRef] [PubMed]

23. Habib, C.A.; Liu, M.; Bawany, N.; Garbern, J.; Krumbein, I.; Mentzel, H.J.; Reichenbach, J.; Magnano, C.; Zivadinov, R.; Haacke, E.M. Assessing abnormal iron content in the deep gray matter of patients with multiple sclerosis versus healthy controls. AJNR Am. J. Neuroradiol. 2012, 33, 252-258. [CrossRef] [PubMed]

24. Hagemeier, J.; Heininen-Brown, M.; Poloni, G.U.; Bergsland, N.; Magnano, C.R.; Durfee, J.; Kennedy, C.; Carl, E.; Weinstock-Guttman, B.; Dwyer, M.G.; et al. Iron deposition in multiple sclerosis lesions measured by susceptibility-weighted imaging filtered phase: A case control study. J. Magn. Reson. Imaging 2012, 36, 73-83. [CrossRef] [PubMed]

25. Paling, D.; Tozer, D.; Wheeler-Kingshott, C.; Kapoor, R.; Miller, D.H.; Golay, X. Reduced R2' in multiple sclerosis normal appearing white matter and lesions may reflect decreased myelin and iron content. J. Neurol. Neurosurg. Psychiatry 2012, 83, 785-792. [CrossRef] [PubMed]

26. Tourdias, T.; Roggerone, S.; Filippi, M.; Kanagaki, M.; Rovaris, M.; Miller, D.H.; Petry, K.G.; Brochet, B.; Pruvo, J.P.; Radue, E.W.; et al. Assessment of disease activity in multiple sclerosis phenotypes with combined gadolinium- and superparamagnetic iron oxide-enhanced MR imaging. Radiology 2012, 264, 225-233. [CrossRef] [PubMed]

27. Williams, R.; Buchheit, C.L.; Berman, N.E.J.; Levine, S.M. Pathogenic implications of iron accumulation in multiple sclerosis. J. Neurochem. 2012, 120, 7-25. [CrossRef] [PubMed]

28. Bagnato, F.; Hametner, S.; Welch, E.B. Visualizing iron in multiple sclerosis. Magn. Reson. Imaging 2013, 31, 376-384. [CrossRef] [PubMed]

29. Hagemeier, J.; Yeh, E.A.; Brown, M.H.; Bergsland, N.; Dwyer, M.G.; Carl, E.; Weinstock-Guttman, B.; Zivadinov, R. Iron content of the pulvinar nucleus of the thalamus is increased in adolescent multiple sclerosis. Mult. Scler. 2013, 19, 567-576. [CrossRef] [PubMed] 
30. Nathoo, N.; Agrawal, S.; Wu, Y.; Haylock-Jacobs, S.; Yong, V.W.; Foniok, T.; Barnes, S.; Obenaus, A.; Dunn, J.F. Susceptibility-weighted imaging in the experimental autoimmune encephalomyelitis model of multiple sclerosis indicates elevated deoxyhemoglobin, iron deposition and demyelination. Mult. Scler. 2013, 19, 721-731. [CrossRef] [PubMed]

31. Walsh, A.J.; Lebel, R.M.; Eissa, A.; Blevins, G.; Catz, I.; Lu, J.Q.; Resch, L.; Johnson, E.S.; Emery, D.J.; Warren, K.G.; et al. Multiple sclerosis: Validation of MR imaging for quantification and detection of iron. Radiology 2013, 267, 531-542. [CrossRef] [PubMed]

32. Blazejewska, A.I.; Al-Radaideh, A.M.; Wharton, S.; Lim, S.Y.; Bowtell, R.W.; Constantinescu, C.S.; Gowland, P.A. Increase in the iron content of the substantia nigra and red nucleus in multiple sclerosis and clinically isolated syndrome: A 7 Tesla MRI study. J. Magn. Reson. Imaging 2014, 1070, 1065-1070. [CrossRef] [PubMed]

33. Haider, L.; Simeonidou, C.; Steinberger, G.; Hametner, S.; Grigoriadis, N.; Deretzi, G.; Kovacs, G.G.; Kutzelnigg, A.; Lassmann, H.; Frischer, J.M. Multiple sclerosis deep grey matter: the relation between demyelination, neurodegeneration, inflammation and iron. J. Neurol. Neurosurg. Psychiatry 2014, 85, 1386-1395. [CrossRef] [PubMed]

34. Raz, E.; Branson, B.; Jensen, J.H.; Bester, M.; Babb, J.S.; Herbert, J.; Grossman, R.I.; Inglese, M. Relationship between iron accumulation and white matter injury in multiple sclerosis: A case-control study. J. Neurol. 2014, 262, 402-409. [CrossRef] [PubMed]

35. Ropele, S.; Kilsdonk, I.D.; Wattjes, M.P.; Langkammer, C.; de Graaf, W.L.; Frederiksen, J.L.; Larsson, H.B.; Yiannakas, M.; Wheeler-Kingshott, C.A.; Enzinger, C.; et al. Determinants of iron accumulation in deep grey matter of multiple sclerosis patients. Mult. Scler. 2014, 20, 1692-1698. [CrossRef] [PubMed]

36. Stankiewicz, J.M.; Neema, M.; Ceccarelli, A. Iron and multiple sclerosis. Neurobiol. Aging 2014, 35, S51-S58. [CrossRef] [PubMed]

37. Stephenson, E.; Nathoo, N.; Mahjoub, Y.; Dunn, J.F.; Yong, V.W. Iron in multiple sclerosis: roles in neurodegeneration and repair. Nat. Rev. Neurol. 2014, 10, 459-468. [CrossRef] [PubMed]

38. Walsh, A.J.; Blevins, G.; Lebel, R.M.; Seres, P.; Emery, D.J.; Wilman, A.H. Longitudinal MR imaging of iron in multiple sclerosis: An imaging marker of disease. Radiology 2014, 270, 186-196. [CrossRef] [PubMed]

39. Du, S.; Sah, S.K.; Zeng, C.; Wang, J.; Liu, Y.; Xiong, H.; Li, Y. Iron deposition in the gray matter in patients with relapse-remitting multiple sclerosis: A longitudinal study using three-dimensional (3D)-enhanced T2*-weighted angiography (ESWAN). Eur. J. Radiol. 2015, 84, 1325-1332. [CrossRef] [PubMed]

40. Khalil, M.; Langkammer, C.; Pichler, A.; Pinter, D.; Gattringer, T.; Bachmaier, G.; Ropele, S.; Fuchs, S.; Enzinger, C.; Fazekas, F. Dynamics of brain iron levels in multiple sclerosis: A longitudinal 3T MRI study. Neurology 2015, 84, 2396-2402. [CrossRef] [PubMed]

41. Wisnieff, C.; Ramanan, S.; Olesik, J.; Gauthier, S.; Wang, Y.; Pitt, D. Quantitative susceptibility mapping (QSM) of white matter multiple sclerosis lesions: Interpreting positive susceptibility and the presence of iron. Magn. Reson. Med. 2015, 74, 564-570. [CrossRef] [PubMed]

42. Chen, W.; Gauthier, S.A.; Gupta, A.; Comunale, J.; Liu, T.; Wang, S.; Pei, M.; Pitt, D.; Wang, Y. Quantitative susceptibility mapping of multiple sclerosis lesions at various ages. Radiology 2014, 271, 183-192. [CrossRef] [PubMed]

43. Kakeda, S.; Futatsuya, K.; Ide, S.; Watanabe, K.; Miyata, M.; Moriya, J.; Ogasawara, A.; Sato, T.; Narimatsu, H.; Okada, K.; et al. Improved detection of cortical gray matter involvement in multiple sclerosis with quantitative susceptibility mapping. Acad. Radiol. 2015, 22, 1427-1432. [CrossRef] [PubMed]

44. De Rochefort, L.; Liu, T.; Kressler, B.; Liu, J.; Spincemaille, P.; Lebon, V.; Wu, J.; Wang, Y. Quantitative susceptibility map reconstruction from MR phase data using bayesian regularization: Validation and application to brain imaging. Magn. Reson. Med. 2010, 63, 194-206. [CrossRef] [PubMed]

45. Wang, Y.; Liu, T. Quantitative susceptibility mapping (QSM): Decoding MRI data for a tissue magnetic biomarker. Magn. Reson. Med. 2015, 73, 82-101. [CrossRef] [PubMed]

46. Langkammer, C.; Liu, T.; Khalil, M.; Enzinger, C.; Jehna, M.; Fuchs, S.; Fazekas, F.; Wang, Y.; Ropele, S. Quantitative susceptibility mapping in multiple sclerosis. Radiology 2013, 267, 551-559. [CrossRef] [PubMed]

47. Connor, J.R.; Menzies, S.L.; St Martin, S.M.; Mufson, E.J. A histochemical study of iron, transferrin, and ferritin in Alzheimer's diseased brains. J. Neurosci. Res. 1992, 31, 75-83. [CrossRef] [PubMed] 
48. Fukunaga, M.; Li, T.-Q.; van Gelderen, P.; de Zwart, J.A.; Shmueli, K.; Yao, B.; Lee, J.; Maric, D.; Aronova, M.A.; Zhang, G.; et al. Layer-specific variation of iron content in cerebral cortex as a source of MRI contrast. Proc. Natl. Acad. Sci. USA 2010, 107, 3834-3839. [CrossRef] [PubMed]

49. Connor, J.R.; Menzies, S.L. Cellular management of iron in the brain. J. Neurol. Sci. 1995, 134, 33-44. [CrossRef]

50. Koeppen, A.H. The history of iron in the brain. J. Neurol. Sci. 1995, 134, 1-9. [CrossRef]

51. Lassmann, H. Mechanisms of white matter damage in multiple sclerosis. Glia 2014, 62, 1816-1830. [CrossRef] [PubMed]

52. Houk, R.S.; Fassel, V.A.; Flesch, G.D.; Svec, H.J.; Gray, A.L.; Taylor, C.E. Inductively coupled argon plasma as an ion source for mass spectrometric determination of trace elements. Anal. Chem. 1980, 52, 2283-2289. [CrossRef]

53. Watt, F.; Landsberg, J. Nuclear microscopy: Biomedical applications. Nucl. Instrum. Meth. B 1993, 77, $249-260$. [CrossRef]

54. Hallgren, B.; Sourander, P. The effect of age on the non-haemin iron in the human brain. J. Neurochem. 1958, 3, 41-51. [CrossRef] [PubMed]

55. Loeffler, D.A.; Connor, J.R.; Juneau, P.L.; Snyder, B.S.; Kanaley, L.; DeMaggio, A.J.; Nguyen, H.; Brickman, C.M.; LeWitt, P.A. Transferrin and iron in normal, Alzheimer's disease, and Parkinson's disease brain regions. J. Neurochem. 1995, 65, 710-724. [CrossRef] [PubMed]

56. Walsh, A. The application of atomic absorption spectra to chemical analysis. Spectrochim. Acta 1955, 7, 108-117. [CrossRef]

57. Riederer, P.; Sofic, E.; Rausch, W.D.; Schmidt, B.; Reynolds, G.P.; Jellinger, K.; Youdim, M.B.H. Transition metals, ferritin, glutathione, and ascorbic acid in parkinsonian brains. J. Neurochem. 1989, 52, 515-520. [CrossRef] [PubMed]

58. Sofic, E.; Paulus, W.; Jellinger, K.; Riederer, P.; Youdim, M.B. Selective increase of iron in substantia nigra zona compacta of parkinsonian brains. J. Neurochem. 1991, 56, 978-982. [CrossRef] [PubMed]

59. Deibel, M.A.; Landsberger, S.; Wu, D.; Ehmann, W.D. Non-destructive analysis of copper in human brain tissue by neutron activation analysis using coincidence and anti-coincidence techniques. J. Radioanal. Nucl. Chem. 1997, 217, 153-155. [CrossRef]

60. Brooks, D.J.; Luthert, P.; Gadian, D.; Marsden, C.D. Does signal-attenuation on high-field T2-weighted MRI of the brain reflect regional cerebral iron deposition? Observations on the relationship between regional cerebral water proton T2 values and iron levels. J. Neurol. Neurosurg. Psychiatry 1989, 52, 108-111. [CrossRef] [PubMed]

61. Deibel, M.A.; Ehmann, W.D.; Markesbery, W.R. Copper, iron, and zinc imbalances in severely degenerated brain regions in Alzheimer's disease: Possible relation to oxidative stress. J. Neurol. Sci. 1996, 143, 137-142. [CrossRef]

62. Tohno, S.; Ishizaki, T.; Shida, Y.; Tohno, Y.; Minami, T.; Mahakkanukrauh, P. Element distribution in visual system, the optic chiasma, lateral geniculate body, and superior colliculus. Biol. Trace Elem. Res. 2010, 142, 335-349. [CrossRef] [PubMed]

63. Tohno, Y.; Tohno, S.; Ongkana, N.; Suwannahoy, P.; Azuma, C.; Minami, T.; Mahakkanukrauh, P. Age-related changes of elements and relationships among elements in human hippocampus, dentate gyrus, and fornix. Biol. Trace Elem. Res. 2010, 138, 42-52. [CrossRef] [PubMed]

64. Haacke, E.M.; Miao, Y.; Liu, M.; Habib, C.A.; Katkuri, Y.; Liu, T.; Yang, Z.; Lang, Z.; Hu, J.; Wu, J. Correlation of putative iron content as represented by changes in R2* and phase with age in deep gray matter of healthy adults. J. Magn. Reson. Imaging 2010, 32, 561-576. [CrossRef] [PubMed]

65. Li, T.-Q.; van Gelderen, P.; Merkle, H.; Talagala, L.; Koretsky, A.P.; Duyn, J. Extensive heterogeneity in white matter intensity in high-resolution T2*-weighted MRI of the human brain at 7.0 T. Neuroimage 2006, 32, 1032-1040. [CrossRef] [PubMed]

66. Yao, B.; Li, T.-Q.; van Gelderen, P.; Shmueli, K.; de Zwart, J.A.; Duyn, J.H. Susceptibility contrast in high field MRI of human brain as a function of tissue iron content. Neuroimage 2009, 44, 1259-1266. [CrossRef] [PubMed]

67. Li, T.-Q.; Yao, B.; van Gelderen, P.; Merkle, H.; Dodd, S.; Talagala, L.; Koretsky, A.P.; Duyn, J. Characterization of $2^{*}$ heterogeneity in human brain white matter. Magn. Reson. Med. 2009, 62, 1652-1657. [CrossRef] [PubMed] 
68. Oros-Peusquens, A.M.; Matusch, A.; Becker, J.S.; Shah, N.J. Automatic segmentation of tissue sections using the multielement information provided by LA-ICP-MS imaging and k-means cluster analysis. Int. J. Mass Spectrom. 2011, 307, 245-252. [CrossRef]

69. Becker, J.S.; Zoriy, M.; Pickhardt, C.; Damoc, E.; Juhacz, G.; Palkovits, M.; Przybylski, M. Determination of phosphorus-, copper-, and zinc-containing human brain proteins by LA-ICPMS and MALDI-FTICR-MS. Anal. Chem. 2005, 77, 5851-5860. [CrossRef] [PubMed]

70. Becker, J.S. Bioimaging of metals in brain tissue from micrometre to nanometre scale by laser ablation inductively coupled plasma mass spectrometry: State of the art and perspectives. Int. J. Mass Spectrom. 2010, 289, 65-75. [CrossRef]

71. Zheng, W.; Nichol, H.; Liu, S.; Cheng, Y.-C.N.; Haacke, E.M. Measuring iron in the brain using quantitative susceptibility mapping and X-ray fluorescence imaging. Neuroimage 2013, 78, 68-74. [CrossRef] [PubMed]

72. McCrea, R.P.E.; Harder, S.L.; Martin, M.; Buist, R.; Nichol, H. A comparison of rapid-scanning X-ray fluorescence mapping and magnetic resonance imaging to localize brain iron distribution. Eur. J. Radiol. 2008, 68, S109-S113. [CrossRef] [PubMed]

73. Hopp, K.; Popescu, B.F.G.; McCrea, R.P.E.; Harder, S.L.; Robinson, C.A.; Haacke, M.E.; Rajput, A.H.; Rajput, A.; Nichol, H. Brain iron detected by SWI high pass filtered phase calibrated with synchrotron X-ray fluorescence. J. Magn. Reson. Imaging 2010, 31, 1346-1354. [CrossRef] [PubMed]

74. Antharam, V.; Collingwood, J.F.; Bullivant, J.-P.; Davidson, M.R.; Chandra, S.; Mikhaylova, A.; Finnegan, M.E.; Batich, C.; Forder, J.R.; Dobson, J. High field magnetic resonance microscopy of the human hippocampus in Alzheimer's disease: Quantitative imaging and correlation with iron. Neuroimage 2012, 59, 1249-1260. [CrossRef] [PubMed]

75. Ryan, C.G.; Kirkham, R.; Siddons, D.P.; Dunn, P.A.; Laird, J.S.; Kuczewski, A.; Moorhead, G.; de Geronimo, G.; Davey, P.; Jensen, M.; et al. The Maia 384 detector array in a nuclear microprobe: A platform for high definition PIXE elemental imaging. Nucl. Instrum. Meth. B 2010, 268, 1899-1902. [CrossRef]

76. Meinecke, C.; Morawski, M.; Reinert, T.; Arendt, T.; Butz, T. Cellular distribution and localisation of iron in adult rat brain (substantia nigra). Nucl. Instrum. Meth. B 2006, 249, 688-691. [CrossRef]

77. Butz, T.; Meinecke, C.; Morawski, M.; Reinert, T.; Schwertner, M.; Spemann, D.; Vogt, J. Morphological and elemental characterisation with the high-energy ion-nanoprobe LIPSION. Appl. Surf. Sci. 2005, 252, 43-48. [CrossRef]

78. Morawski, M.; Meinecke, C.; Reinert, T.; Dorffel, A.; Riederer, P.; Arendt, T.; Butz, T. Determination of trace elements in the human substantia nigra. Nucl. Instrum. Meth. B 2005, 231, 224-228. [CrossRef]

79. Barapatre, N.; Morawski, M.; Butz, T.; Reinert, T. Trace element mapping in parkinsonian brain by quantitative ion beam microscopy. Nucl. Instrum. Meth. B 2010, 268, 2156-2159. [CrossRef]

80. Fiedler, A.; Reinert, T.; Morawski, M.; Bruckner, G.; Arendt, T.; Butz, T. Intracellular iron concentration of neurons with and without perineuronal nets. Nucl. Instrum. Meth. B 2007, 260, 153-158. [CrossRef]

81. Stüber, C.; Morawski, M.; Schäfer, A.; Labadie, C.; Wähnert, M.; Leuze, C.; Streicher, M.; Barapatre, N.; Reimann, K.; Geyer, S.; et al. Myelin and iron concentration in the human brain: A quantitative study of MRI contrast. Neuroimage 2014, 93, 95-106. [CrossRef] [PubMed]

82. Vymazal, J.; Brooks, R.A.; Zak, O.; McRill, C.; Shen, C.; di Chiro, G. T1 and T2 of ferritin at different field strengths: Effect on MRI. Magn. Reson. Med. 1992, 27, 368-374. [CrossRef] [PubMed]

83. Vymazal, J.; Brooks, R.A.; Patronas, N.; Hajek, M.; Bulte, J.W.; di Chiro, G. Magnetic resonance imaging of brain iron in health and disease. J. Neurol. Sci. 1995, 134, 19-26. [CrossRef]

84. Ogg, R.J.; Steen, R.G. Age-related changes in brain T1 are correlated with iron concentration. Magn. Reson. Med. 1998, 40, 749-753. [CrossRef] [PubMed]

85. Rooney, W.D.; Johnson, G.; Li, X.; Cohen, E.R.; Kim, S.-G.; Ugurbil, K.; Springer, C.S. Magnetic field and tissue dependencies of human brain longitudinal $1 \mathrm{H}_{2} \mathrm{O}$ relaxation in vivo. Magn. Reson. Med. 2007, 57, 308-318. [CrossRef] [PubMed]

86. Vymazal, J.; Brooks, R.A.; Baumgarner, C.; Tran, V.; Katz, D.; Bulte, J.W.; Bauminger, R.; di Chiro, G. The relation between brain iron and NMR relaxation times: An in vitro study. Magn. Reson. Med. 1996, 35, 56-61. [CrossRef] [PubMed]

87. Langkammer, C.; Krebs, N.; Goessler, W.; Scheurer, E.; Ebner, F.; Yen, K.; Fazekas, F.; Ropele, S. Quantitative MR imaging of brain iron: A postmortem validation study. Radiology 2010, 257, 455-462. [CrossRef] [PubMed] 
88. Neema, M.; Arora, A.; Healy, B.C.; Guss, Z.D.; Brass, S.D.; Duan, Y.; Buckle, G.J.; Glanz, B.I.; Stazzone, L.; Khoury, S.J.; et al. Deep gray matter involvement on brain MRI scans is associated with clinical progression in multiple sclerosis. J. Neuroimaging 2009, 19, 3-8. [CrossRef] [PubMed]

89. Frahm, J.; Haase, A.; Matthaei, D. Rapid NMR imaging of dynamic processes using the flash technique. Magn. Reson. Med. 1986, 3, 321-327. [CrossRef] [PubMed]

90. Ordidge, R.J.; Gorell, J.M.; Deniau, J.C.; Knight, R.A.; Helpern, J.A. Assessment of relative brain iron concentrations using T2-weighted and T2*-weighted MRI at 3 Tesla. Magn. Reson. Med. 1994, 32, 335-341. [CrossRef] [PubMed]

91. Chavhan, G.B.; Babyn, P.S.; Thomas, B.; Shroff, M.M.; Haacke, E.M. Principles, techniques, and applications of T2*-based MR imaging and its special applications. Radiographics 2009, 29, 1433-1449. [CrossRef] [PubMed]

92. Peters, A.M.; Brookes, M.J.; Hoogenraad, F.G.; Gowland, P.A.; Francis, S.T.; Morris, P.G.; Bowtell, R. T2* measurements in human brain at 1.5, 3 and 7 T. Magn. Reson. Imaging 2007, 25, 748-753. [CrossRef] [PubMed]

93. Rauscher, A.; Sedlacik, J.; Barth, M.; Mentzel, H.-J.; Reichenbach, J.R. Magnetic susceptibility-weighted MR phase imaging of the human brain. AJNR Am. J. Neuroradiol. 2005, 26, 736-742. [PubMed]

94. Jensen, J.H.; Szulc, K.; Hu, C.; Ramani, A.; Lu, H.; Xuan, L.; Falangola, M.F.; Chandra, R.; Knopp, E.A.; Schenck, J.; et al. Magnetic field correlation as a measure of iron-generated magnetic field inhomogeneities in the brain. Magn. Reson. Med. 2009, 61, 481-485. [CrossRef] [PubMed]

95. Jensen, J.H.; Chandra, R.; Ramani, A.; Lu, H.; Johnson, G.; Lee, S.-P.; Kaczynski, K.; Helpern, J.A. Magnetic field correlation imaging. Magn. Reson. Med. 2006, 55, 1350-1361. [CrossRef] [PubMed]

96. Ogg, R.J. The correlation between phase shifts in gradient-echo MR images and regional brain iron concentration. Magn. Reson. Imaging 1999, 17, 1141-1148. [CrossRef]

97. Duyn, J.H.; van Gelderen, P.; Li, T.-Q.; de Zwart, J.A.; Koretsky, A.P.; Fukunaga, M. High-field MRI of brain cortical substructure based on signal phase. Proc. Natl. Acad. Sci. USA 2007, 104, 11796-11801. [CrossRef] [PubMed]

98. Deistung, A.; Schäfer, A.; Schweser, F.; Biedermann, U.; Turner, R.; Reichenbach, J.R. Toward in vivo histology: A comparison of quantitative susceptibility mapping (QSM) with magnitude-, phase-, and R2*-imaging at ultra-high magnetic field strength. Neuroimage 2013, 65, 299-314. [CrossRef] [PubMed]

99. Li, J.; Chang, S.; Liu, T.; Wang, Q.; Cui, D.; Chen, X.; Jin, M.; Wang, B.; Pei, M.; Wisnieff, C.; et al. Reducing the object orientation dependence of susceptibility effects in gradient echo MRI through quantitative susceptibility mapping. Magn. Reson. Med. 2012, 68, 1563-1569. [CrossRef] [PubMed]

100. Wang, S.; Lou, M.; Liu, T.; Cui, D.; Chen, X.; Wang, Y. Hematoma volume measurement in gradient echo MRI using quantitative susceptibility mapping. Stroke 2013, 44, 2315-2317. [CrossRef] [PubMed]

101. Ogawa, S.; Menon, R.S.; Tank, D.W.; Kim, S.G.; Merkle, H.; Ellermann, J.M.; Ugurbil, K. Functional brain mapping by blood oxygenation level-dependent contrast magnetic resonance imaging. A comparison of signal characteristics with a biophysical model. Biophys. J. 1993, 64, 803-812. [CrossRef]

102. Davis, T.L.; Kwong, K.K.; Weisskoff, R.M.; Rosen, B.R. Calibrated functional MRI: Mapping the dynamics of oxidative metabolism. Proc. Natl. Acad. Sci. USA 1998, 95, 1834-1839. [CrossRef] [PubMed]

103. Boxerman, J.L.; Hamberg, L.M.; Rosen, B.R.; Weisskoff, R.M. MR contrast due to intravascular magnetic susceptibility perturbations. Magn. Reson. Med. 1995, 34, 555-566. [CrossRef] [PubMed]

104. Kennan, R.P.; Zhong, J.; Gore, J.C. Intravascular susceptibility contrast mechanisms in tissues. Magn. Reson. Med. 1994, 31, 9-21. [CrossRef] [PubMed]

105. Yablonskiy, D.A.; Haacke, E.M. Theory of NMR signal behavior in magnetically inhomogeneous tissues: The static dephasing regime. Magn. Reson. Med. 1994, 32, 749-763. [CrossRef] [PubMed]

106. Liu, J.; Liu, T.; de Rochefort, L.; Ledoux, J.; Khalidov, I.; Chen, W.; Tsiouris, A.J.; Wisnieff, C.; Spincemaille, P.; Prince, M.R.; et al. Morphology enabled dipole inversion for quantitative susceptibility mapping using structural consistency between the magnitude image and the susceptibility map. Neuroimage 2012, 59, 2560-2568. [CrossRef] [PubMed]

107. Liu, T.; Wisnieff, C.; Lou, M.; Chen, W.; Spincemaille, P.; Wang, Y. Nonlinear formulation of the magnetic field to source relationship for robust quantitative susceptibility mapping. Magn. Reson. Med. 2013, 69, 467-476. [CrossRef] [PubMed]

108. Li, L.; Leigh, J.S. Quantifying arbitrary magnetic susceptibility distributions with MR. Magn. Reson. Med. 2004, 51, 1077-1082. [CrossRef] [PubMed] 
109. Haacke, E.M.; Cheng, N.Y.C.; House, M.J.; Liu, Q.; Neelavalli, J.; Ogg, R.J.; Khan, A.; Ayaz, M.; Kirsch, W.; Obenaus, A. Imaging iron stores in the brain using magnetic resonance imaging. Magn. Reson. Imaging 2005, 23, 1-25. [CrossRef] [PubMed]

110. Shmueli, K.; de Zwart, J.A.; van Gelderen, P.; Li, T.-Q.; Dodd, S.J.; Duyn, J.H. Magnetic susceptibility mapping of brain tissue in vivo using MRI phase data. Magn. Reson. Med. 2009, 62, 1510-1522. [CrossRef] [PubMed]

111. De Rochefort, L.; Brown, R.; Prince, M.R.; Wang, Y. Quantitative MR susceptibility mapping using piece-wise constant regularized inversion of the magnetic field. Magn. Reson. Med. 2008, 60, 1003-1009. [CrossRef] [PubMed]

112. Yeo, D.T.B.; Fessler, J.A.; Kim, B. Motion robust magnetic susceptibility and field inhomogeneity estimation using regularized image restoration techniques for fMRI. Med. Image Comput. Comput. Assist. Interv. 2008, 11, 991-998. [PubMed]

113. Liu, T.; Spincemaille, P.; de Rochefort, L.; Kressler, B.; Wang, Y. Calculation of susceptibility through multiple orientation sampling (COSMOS): A method for conditioning the inverse problem from measured magnetic field map to susceptibility source image in MRI. Magn. Reson. Med. 2009, 61, 196-204. [CrossRef] [PubMed]

114. Wang, Y.; de Rochefort, L.; Liu, T.; Kressler, B. Magnetic source MRI: A new quantitative imaging of magnetic biomarkers. Conf. Proc. IEEE Eng. Med. Biol. Soc. 2009, 2009, 53-56. [PubMed]

115. Schweser, F.; Sommer, K.; Deistung, A.; Reichenbach, J.R. Quantitative susceptibility mapping for investigating subtle susceptibility variations in the human brain. Neuroimage 2012, 62, 2083-2100. [CrossRef] [PubMed]

116. Kressler, B.; de Rochefort, L.; Liu, T.; Spincemaille, P.; Jiang, Q.; Wang, Y. Nonlinear regularization for per voxel estimation of magnetic susceptibility distributions from MRI field maps. IEEE Trans. Med. Imaging 2010, 29, 273-281. [CrossRef] [PubMed]

117. Wharton, S.; Schäfer, A.; Bowtell, R. Susceptibility mapping in the human brain using threshold-based k-space division. Magn. Reson. Med. 2010, 63, 1292-1304. [CrossRef] [PubMed]

118. Li, W.; Wu, B.; Liu, C. Quantitative susceptibility mapping of human brain reflects spatial variation in tissue composition. Neuroimage 2011, 55, 1645-1656. [CrossRef] [PubMed]

119. Chen, Z.; Calhoun, V. Computed inverse resonance imaging for magnetic susceptibility map reconstruction. J. Comput. Assist. Tomogr. 2012, 36, 265-274. [CrossRef] [PubMed]

120. Schweser, F.; Deistung, A.; Sommer, K.; Reichenbach, J.R. Toward online reconstruction of quantitative susceptibility maps: Superfast dipole inversion. Magn. Reson. Med. 2013, 69, 1582-1594. [CrossRef] [PubMed]

121. Langkammer, C.; Schweser, F.; Krebs, N.; Deistung, A.; Goessler, W.; Scheurer, E.; Sommer, K.; Reishofer, G.; Yen, K.; Fazekas, F.; et al. Quantitative susceptibility mapping (QSM) as a means to measure brain iron? A post mortem validation study. Neuroimage 2012, 62, 1593-1599. [CrossRef] [PubMed]

122. Wu, B.; Li, W.; Guidon, A.; Liu, C. Whole brain susceptibility mapping using compressed sensing. Magn. Reson. Med. 2012, 67, 137-147. [CrossRef] [PubMed]

123. Bilgic, B.; Fan, A.P.; Polimeni, J.R.; Cauley, S.F.; Bianciardi, M.; Adalsteinsson, E.; Wald, L.L.; Setsompop, K. Fast quantitative susceptibility mapping with L1-regularization and automatic parameter selection. Magn. Reson. Med. 2014, 72, 1444-1459. [CrossRef] [PubMed]

124. Bilgic, B.; Chatnuntawech, I.; Fan, A.P.; Setsompop, K.; Cauley, S.F.; Wald, L.L.; Adalsteinsson, E. Fast image reconstruction with L2-regularization. J. Magn. Reson. Imaging 2014, 40, 181-191. [CrossRef] [PubMed]

125. Tang, J.; Liu, S.; Neelavalli, J.; Cheng, Y.C.N.; Buch, S.; Haacke, E.M. Improving susceptibility mapping using a threshold-based k-space/image domain iterative reconstruction approach. Magn. Reson. Med. 2013, 69, 1396-1407. [CrossRef] [PubMed]

126. Schäfer, A.; Forstmann, B.U.; Neumann, J.; Wharton, S.; Mietke, A.; Bowtell, R.; Turner, R. Direct visualization of the subthalamic nucleus and its iron distribution using high-resolution susceptibility mapping. Hum. Brain Mapp. 2012, 33, 2831-2842. [CrossRef] [PubMed]

127. Liu, C.; Li, W.; Johnson, G.A.; Wu, B. High-field (9.4 T) MRI of brain dysmyelination by quantitative mapping of magnetic susceptibility. Neuroimage 2011, 56, 930-938. [CrossRef] [PubMed]

128. Schenck, J.F. Health and physiological effects of human exposure to whole-body four-Tesla magnetic fields during MRI. Ann. N. Y. Acad. Sci. 1992, 649, 285-301. [CrossRef] [PubMed]

129. Rouault, T.A.; Cooperman, S. Brain iron metabolism. Semin. Pediatr. Neurol. 2006, 13, 142-148. [CrossRef] [PubMed] 
130. Schenck, J.F. The role of magnetic susceptibility in magnetic resonance imaging: MRI magnetic compatibility of the first and second kinds. Med. Phys. 1996, 23, 815-850. [CrossRef] [PubMed]

131. Connor, J.R.; Menzies, S.L.; St. Martin, S.M.; Mufson, E.J. Cellular distribution of transferrin, ferritin, and iron in normal and aged human brains. J. Neurosci. Res. 1990, 27, 595-611. [CrossRef] [PubMed]

132. Zheng, W.; Monnot, A.D. Regulation of brain iron and copper homeostasis by brain barrier systems: Implication in neurodegenerative diseases. Pharmacol. Ther. 2012, 133, 177-188. [CrossRef] [PubMed]

133. Langkammer, C.; Krebs, N.; Goessler, W.; Scheurer, E.; Yen, K.; Fazekas, F.; Ropele, S. Susceptibility induced gray-white matter MRI contrast in the human brain. Neuroimage 2012, 59, 1413-1419. [CrossRef] [PubMed]

134. Connor, J.R.; Menzies, S.L. Relationship of iron to oligodendrocytes and myelination. Glia 1996, 17, 83-93. [CrossRef]

135. Cairo, G.; Bernuzzi, F.; Recalcati, S. A precious metal: Iron, an essential nutrient for all cells. Genes Nutr. 2006, 1, 25-39. [CrossRef] [PubMed]

136. Mosser, D.M.; Edwards, J.P. Exploring the full spectrum of macrophage activation. Nat. Rev. Immunol. 2008, 8, 958-969. [CrossRef] [PubMed]

137. Martinez, F.O.; Helming, L.; Gordon, S. Alternative activation of macrophages: An immunologic functional perspective. Annu. Rev. Immunol. 2009, 27, 451-483. [CrossRef] [PubMed]

138. Gordon, S.; Taylor, P.R. Monocyte and macrophage heterogeneity. Nat. Rev. Immunol. 2005, 5, $953-964$. [CrossRef] [PubMed]

139. Corna, G.; Campana, L.; Pignatti, E.; Castiglioni, A.; Tagliafico, E.; Bosurgi, L.; Campanella, A.; Brunelli, S.; Manfredi, A.A.; Apostoli, P.; et al. Polarization dictates iron handling by inflammatory and alternatively activated macrophages. Haematologica 2010, 95, 1814-1822. [CrossRef] [PubMed]

140. Recalcati, S.; Locati, M.; Marini, A.; Santambrogio, P.; Zaninotto, F.; de Pizzol, M.; Zammataro, L.; Girelli, D.; Cairo, G. Differential regulation of iron homeostasis during human macrophage polarized activation. Eur. J. Immunol. 2010, 40, 824-835. [CrossRef] [PubMed]

141. Xiong, S.; She, H.; Takeuchi, H.; Han, B.; Engelhardt, J.F.; Barton, C.H.; Zandi, E.; Giulivi, C.; Tsukamoto, H. Signaling role of intracellular iron in NF-кB activation. J. Biol. Chem. 2003, 278, 17646-17654. [CrossRef] [PubMed]

142. Chen, L.; Xiong, S.; She, H.; Lin, S.W.; Wang, J.; Tsukamoto, H. Iron causes interactions of TAK1, p21ras, and phosphatidylinositol 3-kinase in caveolae to activate IкB kinase in hepatic macrophages. J. Biol. Chem. 2007, 282, 5582-5588. [CrossRef] [PubMed]

143. Martinez, F.O.; Gordon, S. The M1 and M2 paradigm of macrophage activation: Time for reassessment. F1000Prime Rep. 2014, 6, 1-13. [CrossRef] [PubMed]

144. Yao, B.; Bagnato, F.; Matsuura, E.; Merkle, H.; van Gelderen, P.; Cantor, F.K.; Duyn, J.H. Chronic multiple sclerosis lesions: Characterization with high-field-strength MR imaging. Radiology 2012, 262, 206-215. [CrossRef] [PubMed]

145. Boven, L.A.; van Meurs, M.; van Zwam, M.; Wierenga-Wolf, A.; Hintzen, R.Q.; Boot, R.G.; Aerts, J.M.; Amor, S.; Nieuwenhuis, E.E.; Laman, J.D. Myelin-laden macrophages are anti-inflammatory, consistent with foam cells in multiple sclerosis. Brain 2006, 129, 517-526. [CrossRef] [PubMed]

146. Taetzsch, T.; Levesque, S.; McGraw, C.; Brookins, S.; Luqa, R.; Bonini, M.G.; Mason, R.P.; Oh, U.; Block, M.L. Redox regulation of NF-kB p50 and M1 polarization in microglia. Glia 2015, 63, 423-440. [CrossRef] [PubMed]

147. Pitt, D.; Boster, A.; Pei, W.; Wohleb, E.; Jasne, A.; Zachariah, C.R.; Rammohan, K.; Knopp, M.V.; Schmalbrock, P. Imaging cortical lesions in multiple sclerosis with ultra-high-field magnetic resonance imaging. Arch. Neurol. 2010, 67, 812-818. [CrossRef] [PubMed]

148. Yao, B.; Hametner, S.; van Gelderen, P.; Merkle, H.; Chen, C.; Lassmann, H.; Duyn, J.H.; Bagnato, F. 7 Tesla magnetic resonance imaging to detect cortical pathology in multiple sclerosis. PLoS ONE 2014, 9, e108863. [CrossRef] [PubMed]

149. Tjoa, C.W.; Benedict, R.H.B.; Weinstock-Guttman, B.; Fabiano, A.J.; Bakshi, R. MRI T2 hypointensity of the dentate nucleus is related to ambulatory impairment in multiple sclerosis. J. Neurol. Sci. 2005, 234, 17-24. [CrossRef] [PubMed]

150. Neema, M.; Stankiewicz, J.; Arora, A.; Dandamudi, V.S.; Batt, C.E.; Guss, Z.D.; Al-Sabbagh, A.; Bakshi, R. T1- and T2-based MRI measures of diffuse gray matter and white matter damage in patients with multiple sclerosis. J. Neuroimaging 2007, 17, 16s-21s. [CrossRef] [PubMed] 
151. Bermel, R.A.; Puli, S.R.; Rudick, R.A.; Weinstock-Guttman, B.; Fisher, E.; Munschauer, F.E.; Bakshi, R. Prediction of longitudinal brain atrophy in multiple sclerosis by gray matter magnetic resonance imaging $\mathrm{T} 2$ hypointensity. Arch. Neurol. 2005, 62, 1371-1376. [CrossRef] [PubMed]

152. Brass, S.D.; Benedict, R.H.B.; Weinstock-Guttman, B.; Munschauer, F.; Bakshi, R. Cognitive impairment is associated with subcortical magnetic resonance imaging grey matter $\mathrm{T} 2$ hypointensity in multiple sclerosis. Mult. Scler. 2006, 12, 437-444. [CrossRef] [PubMed]

153. Altamura, S.; Muckenthaler, M.U. Iron toxicity in diseases of aging: Alzheimer's disease, Parkinson's disease and atherosclerosis. J. Alzheimers Dis. 2009, 16, 879-895. [PubMed]

154. Brass, S.D.; Chen, N.K.; Mulkern, R.V.; Bakshi, R. Magnetic resonance imaging of iron deposition in neurological disorders. Top. Magn. Reson. Imaging 2006, 17, 31-40. [CrossRef] [PubMed]

155. Oakley, A.E.; Collingwood, J.F.; Dobson, J.; Love, G.; Perrott, H.R.; Edwardson, J.A.; Elstner, M.; Morris, C.M. Individual dopaminergic neurons show raised iron levels in parkinson disease. Neurology 2007, 68, 1820-1825. [CrossRef] [PubMed]

156. Bakshi, R.; Thompson, A.J.; Rocca, M.A.; Pelletier, D.; Dousset, V.; Barkhof, F.; Inglese, M.; Guttmann, C.R.; Horsfield, M.A.; Filippi, M. MRI in multiple sclerosis: Current status and future prospects. Lancet Neurol. 2008, 7, 615-625. [CrossRef]

157. Duyn, J.H. High-field MRI of brain iron. Methods Mol. Biol. 2011, 711, 239-249. [PubMed]

158. Schmierer, K.; Parkes, H.G.; So, P.W.; An, S.F.; Brandner, S.; Ordidge, R.J.; Yousry, T.A.; Miller, D.H. High field (9.4 Tesla) magnetic resonance imaging of cortical grey matter lesions in multiple sclerosis. Brain 2010, 133, 858-867. [CrossRef] [PubMed]

159. Filippi, M.; Evangelou, N.; Kangarlu, A.; Inglese, M.; Mainero, C.; Horsfield, M.A.; Rocca, M.A. Ultra-high-field MR imaging in multiple sclerosis. J. Neurol. Neurosurg. Psychiatry 2014, 85, 60-66. [CrossRef] [PubMed]

160. MacKay, A.L.; Vavasour, I.M.; Rauscher, A.; Kolind, S.H.; Mädler, B.; Moore, G.R.W.; Traboulsee, A.L.; Li, D.K.B.; Laule, C. MR relaxation in multiple sclerosis. Neuroimaging Clin. N. Am. 2009, 19, 1-26. [CrossRef] [PubMed]

161. Geurts, J.J.G.; Bö, L.; Pouwels, P.J.W.; Castelijns, J.A.; Polman, C.H.; Barkhof, F. Cortical lesions in multiple sclerosis: Combined postmortem MR imaging and histopathology. AJNR Am. J. Neuroradiol. 2005, 26, 572-577. [PubMed]

162. Yablonskiy, D.A.; Luo, J.; Sukstanskii, A.L.; Iyer, A.; Cross, A.H. Biophysical mechanisms of MRI signal frequency contrast in multiple sclerosis. Proc. Natl. Acad. Sci. USA 2012, 109, 14212-14217. [CrossRef] [PubMed]

163. Lee, J.; Shmueli, K.; Kang, B.-T.; Yao, B.; Fukunaga, M.; van Gelderen, P.; Palumbo, S.; Bosetti, F.; Silva, A.C.; Duyn, J.H. The contribution of myelin to magnetic susceptibility-weighted contrasts in high-field MRI of the brain. Neuroimage 2012, 59, 3967-3975. [CrossRef] [PubMed]

164. Wiggermann, V.; Hernández Torres, E.; Vavasour, I.M.; Moore, G.R.W.; Laule, C.; MacKay, A.L.; Li, D.K.B.; Traboulsee, A.; Rauscher, A. Magnetic resonance frequency shifts during acute MS lesion formation. Neurology 2013, 81, 211-218. [CrossRef] [PubMed]

165. Bian, W.; Harter, K.; Hammond-Rosenbluth, K.E.; Lupo, J.M.; Xu, D.; Kelley, D.A.; Vigneron, D.B.; Nelson, S.J.; Pelletier, D. A serial in vivo 7T magnetic resonance phase imaging study of white matter lesions in multiple sclerosis. Mult. Scler. 2013, 19, 69-75. [CrossRef] [PubMed]

166. Absinta, M.; Sati, P.; Gaitán, M.I.; Maggi, P.; Cortese, I.C.M.; Filippi, M.; Reich, D.S. Seven-Tesla phase imaging of acute multiple sclerosis lesions: A new window into the inflammatory process. Ann. Neurol. 2013, 74, 669-678. [CrossRef] [PubMed]

167. Kollia, K.; Maderwald, S.; Putzki, N.; Schlamann, M.; Theysohn, J.M.; Kraff, O.; Ladd, M.E.; Forsting, M.; Wanke, I. First clinical study on ultra-high-field MR imaging in patients with multiple sclerosis: Comparison of 1.5T and 7T. Am. J. Neuroradiol. 2009, 30, 699-702. [CrossRef] [PubMed]

168. Zivadinov, R.; Dwyer, M.; Markovic-Plese, S.; Hayward, B.; Bergsland, N.; Heininen-Brown, M.; Carl, E.; Kennedy, C.; Dangond, F.; Weinstock-Guttman, B. A pilot, longitudinal, 24-week study to evaluate the effect of interferon $\beta$-1a subcutaneous on changes in susceptibility-weighted imaging-filtered phase assessment of lesions and subcortical deep-gray matter in relapsing-remitting multiple sclerosis. Ther. Adv. Neurol. Disord. 2015, 8, 59-70. [CrossRef] [PubMed] 
169. Grabner, G.; Dal-Bianco, A.; Schernthaner, M.; Vass, K.; Lassmann, H.; Trattnig, S. Analysis of multiple sclerosis lesions using a fusion of 3.0 T FLAIR and 7.0 T SWI phase: FLAIR SWI. J. Magn. Reson. Imaging 2011, 33, 543-549. [CrossRef] [PubMed]

170. Eskreis-Winkler, S.; Deh, K.; Gupta, A.; Liu, T.; Wisnieff, C.; Jin, M.; Gauthier, S.A.; Wang, Y.; Spincemaille, P. Multiple sclerosis lesion geometry in quantitative susceptibility mapping (QSM) and phase imaging. J. Magn. Reson. Imaging 2015, 42, 224-229. [CrossRef] [PubMed]

171. Lebel, R.M.; Eissa, A.; Seres, P.; Blevins, G.; Wilman, A.H. Quantitative high-field imaging of sub-cortical gray matter in multiple sclerosis. Mult. Scler. 2012, 18, 433-441. [CrossRef] [PubMed]

172. Rudko, D.A.; Solovey, I.; Gati, J.S.; Kremenchutzky, M.; Menon, R.S. Multiple sclerosis: Improved identification of disease-relevant changes in gray and white matter by using susceptibility-based MR imaging. Radiology 2014, 272, 851-864. [CrossRef] [PubMed]

173. Mainero, C.; Louapre, C.; Govindarajan, S.T.; Gianni, C.; Nielsen, A.S.; Cohen-Adad, J.; Sloane, J.; Kinkel, R.P. A gradient in cortical pathology in multiple sclerosis by in vivo quantitative $7 \mathrm{~T}$ imaging. Brain 2015, 138, 932-945. [CrossRef] [PubMed]

174. Jonkman, L.E.; Klaver, R.; Fleysher, L.; Inglese, M.; Geurts, J.J.G. Ultra-high-field MRI visualization of cortical multiple sclerosis lesions with T2 and T2*: A postmortem MRI and histopathology study. AJNR Am. J. Neuroradiol. 2015, 36, 2062-2067. [CrossRef] [PubMed]

175. Raj, A.; Pandya, S.; Shen, X.; LoCastro, E.; Nguyen, T.D.; Gauthier, S.A. Multi-compartment T2 relaxometry using a spatially constrained multi-Gaussian model. PLoS ONE 2014, 9, e98391. [CrossRef] [PubMed]

176. Nguyen, T.D.; Wisnieff, C.; Cooper, M.A.; Kumar, D.; Raj, A.; Spincemaille, P.; Wang, Y.; Vartanian, T.; Gauthier, S.A. T2 prep three-dimensional spiral imaging with efficient whole brain coverage for myelin water quantification at 1.5 Tesla. Magn. Reson. Med. 2012, 67, 614-621. [CrossRef] [PubMed]

177. Kumar, D.; Nguyen, T.D.; Gauthier, S.A.; Raj, A. Bayesian algorithm using spatial priors for multiexponential T2 relaxometry from multiecho spin echo MRI. Magn. Reson. Med. 2012, 68, 1536-1543. [CrossRef] [PubMed]

178. Wisnieff, C.; Liu, T.; Spincemaille, P.; Wang, S.; Zhou, D.; Wang, Y. Magnetic susceptibility anisotropy: Cylindrical symmetry from macroscopically ordered anisotropic molecules and accuracy of MRI measurements using few orientations. Neuroimage 2013, 70, 363-376. [CrossRef] [PubMed]

179. Chen, W.; Gauthier, S.; Gupta, A.; Comunale, J.; Liu, T.; Wang, S.; Pei, M.; Pitt, D.; Wang, Y. Dynamic Magnetic Property of Multiple Sclerosis Lesions at Various Ages Measured by Quantitative Susceptibility Mapping; ISMRM: Salt Lake City, UT, USA, 2013; p. 0692.

180. Barber, T.W.; Brockway, J.A.; Higgins, L.S. The density of tissues in and about the head. Acta Neurol. Scand. 1970, 46, 85-92. [CrossRef] [PubMed]

181. Wisnieff, C.; Ryan, R.; Pitt, D.; Wang, Y. Investigation of susceptibility contrast in grey and white matter multiple sclerosis lesions. Proc. Int. Soc. Magn. Reson. Med. 2014, 22, 3403.

182. Wisnieff, C.; Ramanan, S.; Wang, Y.; Pitt, D. Iron in Multiple Sclerosis Lesions Can be Detected by Larger Volumes on Quantitative Susceptibility Mapping Than T2 Weighted Imaging. Mult. Scler. J. 2014, $20,262$.

183. Ladewig, G.; Jestaedt, L.; Misselwitz, B.; Solymosi, L.; Toyka, K.; Bendszus, M.; Stoll, G. Spatial diversity of blood-brain barrier alteration and macrophage invasion in experimental autoimmune encephalomyelitis: A comparative MRI study. Exp. Neurol. 2009, 220, 207-211. [CrossRef] [PubMed]

184. Gaitán, M.I.; Shea, C.D.; Evangelou, I.E.; Stone, R.D.; Fenton, K.M.; Bielekova, B.; Massacesi, L.; Reich, D.S. Evolution of the blood-brain barrier in newly forming multiple sclerosis lesions. Ann. Neurol. 2011, 70, $22-29$. [CrossRef] [PubMed]

185. Zhang, Y.; Gauthier, S.; Tu, L.; Gupta, A.; Comunale, J.; Chiang, G.C.; Zhou, D.; Wang, Y. Increase in Magnetic Susceptibility After MS Lesion Formation and Potential Diagnostic Utility. In Proceedings of the ECTRIMS, Barcelona, Spain, 7-10 October 2015; p. 986.

(C) 2016 by the authors; licensee MDPI, Basel, Switzerland. This article is an open access article distributed under the terms and conditions of the Creative Commons by Attribution (CC-BY) license (http:/ / creativecommons.org/licenses/by/4.0/). 